\title{
La sindicación de acciones
}

\section{Christian Alberto Robleto Arana ${ }^{54}$ \\ Doctorando en Derecho por la Universidad Centroamericana UCA \\ mid@ns.uca.edu.ni}

Fecha de recepción: 10 de noviembre 2012 / Fecha de aceptación: 6 de abril 2013

\section{Resumen}

Los pactos parasocietarios constituyen en Nicaragua, una de las instituciones jurídicas mercantiles que merece ser estudiada a la luz del derecho vigente, independientemente que en nuestro derecho no existe una regulación legal, ni jurisprudencial propia, como lo tienen los países objeto de estudio, en especial Perú, Chile, España, Brasil, Italia, Francia. Por esta razón, el presente artículo de investigación analiza críticamente la naturaleza de los sindicatos de acciones identificándolos como contratos plurilaterales, con carácter asociativo, destinados para las empresas y accesorio al contrato de sociedad; destacándose su valor jurídico y eficacia según el derecho vigente. Asimismo, se logra enfatizar las principales características de cada uno y los vacíos y deficiencias normativas de los mismos.

\section{Palabras claves}

Pactos parasociales / sindicato de acciones / sindicato de bloqueo / sindicato de administración

54 El presente trabajo es producto de la labor investigadora realizada durante el Período de investigación del Programa de Doctorado "Cuestiones actuales del Derecho", bajo la tutoría académica del Prof. Dr. Jesús Herrera Espinoza, docente de la Facultad de Ciencias Jurídicas, Universidad Centroamericana, Nicaragua 2012. 


\section{Deerecho}

\section{Abstract}

The parasocietarial pacts constitutes in Nicaragua, one of the commercial legal institutionsthat deserves to be studied in light of existing law, regardless in our law there is no legal regulation, or jurisprudence itself as do the countries studied, particularly Peru, Chile, Spain, Brazil, Italy, France. For this reason, this research paper examines critically the nature of the union actions, identified as plurilateral associative contracts with associative nature, designed for companies and accessory to the partnership contract agreement, stressing its legal and effective value at the existing law. It also emphasized the main features of each one and a regulatory gaps and deficiencies thereof.

\section{Keywords}

Shareholder agreements / union actions / union lock / union management

\section{Tabla de contenido}

Introducción.1.Generalidades delos contratos parasocietarios.2.Reconocimiento legal de los contratos parasocietarios. 3. Sindicación de acciones. 3.1 Concepto y alcance. 3.2 Naturaleza jurídica del sindicato de acciones. 3.2.1 Es un contrato de prestaciones plurilaterales autónomas. 3.2.2 Contrato asociativo. 3.2.3 Es un contrato accesorio al contra principal. 3.2.4 Es un contrato parasocietario. 3.2.5 Es un contrato de empresa. 4. Figuras afines al contrato de sindicación de acciones. 4.1 Vonting-agreement. 4.2 Vonting trust. 5. Clases de sindicación de acciones. 5.1 Sindicato de voto. 5.1.1 Modalidades de Sindicato de voto. 5.1.1.1 Sindicato de voto en una sociedad conjunta. 5.1.1.2 Accionistas significativos. 5.2 Sindicato de bloqueo. 5.3 Sindicato financiero. 5.4 Sindicato de la administración. Conclusiones. Lista de Referencias. 


\section{Introducción}

La importancia de estudio de los contratos parasocietarios, en particular, los "sindicato de acciones", radica en analizar el valor de los acuerdos tomados de manera externa a la sociedad; es decir, acuerdos entre socios, entre socios y otras sociedades y socios con terceros. En este sentido, el estudio de este trabajo investigativo tiene como objetivo presentar de manera coherente cómo el sistema legal nicaragüense, en especial el Código de Comercio de 1917 “Cc” y el Código Civil de 1904 "C", a pesar de los vacíos existentes, presentan soluciones sobre la validez y eficacia de los contratos parasocietarios, en particular los sindicatos de acciones.

Los dos primeros temas abordan las características de los contratos parasocietarios tomando como referencia la doctrina mayoritaria y legislación comparada de países americanos y europeos (Perú, Chile, Argentina, Uruguay, Brasil, Francia, España, Italia, Alemania, Estados Unidos); al mismo tiempo se presenta excursos sobre las principales tendencias y aportes del derecho comparado en el Derecho nicaragüense.

El tercer tema desarrolla los sindicatos de acciones y se retoma la importancia práctica de su naturaleza jurídica, analizando de manera vinculante con la legislación nicaragüense, su admisibilidad de acuerdo a las características que se exponen en el presente estudio, entre las que se destaca su carácter plurilateral, asociativo, accesorio, empresarial.

El cuarto tema, analiza figuras análogas al sindicato de acciones, en especial los voting trusts, voting agreement, sociedades conjuntas y accionistas significativos, en cada una de las figuras jurídicas relacionadas se hace un análisis crítico sobre su aplicabilidad en el contexto nacional.

Por último, se desarrolla las clases de sindicatos de acciones, logrando identificar las características más importantes que la definen como sindicados de bloqueo, sindicatos financieros, sindicatos de administración.

\section{Generalidades de los contratos parasocietarios}

Es un acuerdo privado celebrados entre socios o entre socios y terceros, en virtud del cual, los socios convienen sobre diversos asuntos de interés particular, respecto a la sociedad. Los pactos parasocietarios o también denominados pactos extraestatutarios, pueden consistir en realizar determinados actos o abstenerse de realizarlos, así como la fijación de políticas de actuación conjunta respecto a su 
tenencia accionario y de su intervención en los actos celebrados por los órganos societarios. Los acuerdos no obligan a la sociedad y no son oponibles respecto a la ley, al contrato social y a los estatutos. Se caracterizan por ser eficaces inter partes. Estos acuerdos no gozan de rango estatutario, pero se rigen por la regla de unanimidad entre sus miembros, tanto a la hora de adoptarlos, como a la hora de modificarlos. Los acuerdos o pactos parasocietarios están ligados al contrato principal y unido por un vínculo de accesoriedad. (Gutiérrez Camacho, 1999; Berges Angós, 2009; Sáez Lacave, 2009; Echaiz Moreno, 2006; Caamacho, SF; Mosquera Alcocer, 2009; Quesnay Casusol, 2009; Álvarez López, 2009; Luceño Olivas, $2010 \&$ Paz-Ares, 2003). Los pactos parasociales suelen agruparse en tres grandes categorías, denominadas por Cándido Paz-Ares (2003), como: Pactos de relación, pactos de atribución, pactos de organización.

Los pactos de relación, se caracterizan por su neutralidad frente la sociedad; en este tipo de pactos los socios establecen vínculos jurídicos sin mediar la sociedad. Es decir, lo característico de este pacto es que no tiene incidencia jurídica apreciable sobre la sociedad. Ejemplos: los pactos que otorgan derechos de preferencias; derechos de venta conjunta; obligaciones de no aumentar el capital por arriba de un determinado porcentaje; obligaciones de ceder o de adquirir las participaciones bajo determinadas condiciones; cláusulas de cobertura de las pérdidas de unos socios por otros; cláusula de distribución de dividendos sobre bases diversas previstas en el contrato y estatuto de la sociedad (Paz-Ares, 2003, pp. 19, 20).

Pactos de atribución, son acuerdos que tiene por objeto beneficiar a la sociedad. Ejemplo: los pactos que establecen financiación adicional por parte de los socios; abstenerse de competir con la sociedad; ofrecer la adquisición de acciones cuando el socio decida transmitirla (Paz-Ares, 2003).

Pactos de organización, este tipo de acuerdo, es uno de los más conflictivos, porque agrupan socios para decidir sobre los propios estatutos de la sociedad, es decir, reglamentan la sociedad, en relación a su funcionamiento y el sistema de toma de decisiones. Se les denomina pactos de control, porque controlan la sociedad. Estos pactos tiene por objeto: interpretar normas estatutarias, sobre la composición de sus órganos, políticas a desarrollar en la compañía, pactos restrictivos de competencia de los administradores; pactos sobre régimen de modificación estatutarias; pactos de arbitraje para deshacer situaciones de bloqueo o deadlock, pactos sobre información a los socios, pactos de contratación de socios y familiares, pactos de disolución de la sociedad, pactos sobre el quórum y mayoría, pactos sobre el ejercicio de derecho de la minoría. Siendo en este caso el sindicato de voto (Paz-Ares, 2003). 
De acuerdo a las definiciones y la clasificación de los contratos parasocietarios, lo que caracteriza este tipo de pacto son los siguientes elementos:

a) Son contratos privados entre los socios. En este particular, nuestro sistema señala el artículo 2435 del Código Civil que define los contratos como acuerdos entre dos o más personas en la que se crea, constituye, modifica un vínculo jurídico. Constituye una de las fuentes de las obligaciones según lo dispuesto en el Art. $1831 \mathrm{C}$ y es fuerza de ley entre las partes contratante (Art. 1836 C). Por la naturaleza del acto que se celebra y al ser accesorio del contrato societario y estatutos, es un contrato mercantil, sometido a las reglas del Código de Comercio, según lo dispuesto en el Art. 82 y siguiente. Son contratos basados en la autonomía privada de las partes (Art. 32 Constitución Política de Nicaragua “Cn”; Arts. 2437, 2479 Código Civil); dichos pactos recaen sobre los derechos de representación de los órganos; derechos de información; derechos económicos, y derechos políticos. Asimismo, se caracterizan por ser inter partes. Es decir, tienen efectos entre las partes que lo celebran, obligándose únicamente a lo pactado(Berges Angós, 2009 \& Quesada Sánchez, 2002).

De acuerdo a la regla general del Art. 2439 del Código Civil de Nicaragua sobre la relatividad de los contratos, los pactos parasocietarios no producirán efectos en la sociedad porque estamos ante un contrato ajeno a la misma y ésta no es parte en la relación jurídica. En consecuencia, ante la falta de cumplimiento del pacto, las partes pueden valerse de todos las acciones ofrecidas por el derecho de obligaciones (acción de daños y perjuicios, acción de cumplimiento, acción de resolución) que pueden minimizar el incumplimiento, con el fin de compeler a la otra para que cumpla y en ningún caso podrá la parte que sufre el incumplimiento accionar los mecanismos previstos para la sociedad en los casos de inobservancia de las disposiciones legales y estatutarias.

b) Los contratos parsocietarios, pueden celebrarse entre socios, entre socios y terceros. Esta característica comprende un esquema distinto a la esfera societaria en donde los socios son accionistas; por lo tanto, en armonía al principio de libertad de contratación, el acto jurídico celebrado entre socios es válido, en consecuencia el acuerdo es fuente de obligaciones (Art. 1831 Código Civil). Asimismo, debe entenderse que el contrato parasocietario no solamente es para actos entre socios de una misma sociedad (socios minoritarios o mayoritarios), sino que también pueden ser entre socios de distintas sociedades (Sociedades conjuntas) o entre socios de una sociedad y terceros (acuerdos entre socios y representantes de otras empresas comerciales 
o industriales con fines económicos). En fin, los pactos parasocietarios, son pactos obligatorios entre las partes vinculantes, pero no pactos societarios de carácter corporativo, por cuanto tienen pleno efecto entre los firmantes.

c) Los contratos parasocietarios son inoponibles a ley, al contrato social y estatuto que rigen a la sociedad. Los convenios para societarios otorgan desde punto de vista jurídico tantos derechos y como obligaciones, al margen del contrato y estatuto de la sociedad. Se reconoce por la doctrina que este contrato es oponible frente a terceros desde un punto de vista real y obligacional, independientemente de los contratos de sindicación que existan. Es decir, que los contratos no pueden perjudicar a terceros (Art.2439 Código Civil).

De acuerdo con Tomas Araya (2011) la oponibilidad habrá que estudiarla desde dos panoramas distintos, es decir, desde los sindicatos totalitarios (todos los socios) y los sindicatos de minoría o mayoría, para determinar su oponibilidad; en este sentido, afirma que en aquellos países en que se requiere el registro del pacto de sindicación a la sociedad, y siendo éste totalitario, entonces, no habrá necesidad de reformar el pacto social, basta el registro que se hace en la sociedad y la buena fe de los socios para que surta efecto en el contrato societario.

En el Derecho Nicaragüense, existen supuestos en los que la regla general de inoponibilidad de los pactos parasociales, tienen efectos en la sociedad, por ejemplo:

- En aquellos pactos en los que se le concede a la sociedad un beneficio, es decir, nos referimos a un contrato de estipulación a favor de terceros, en virtud del Art. 2439 segundo párrafo del Código Civil de Nicaragua, la sociedad estaría legitimada para el cumplimiento del pacto.

- Cuando todas las partes del pacto parasocial son las mismas del contrato social; es decir, todos los socios de la sociedad. En este particular, la voluntad del pacto sería idéntica a la de la Junta General de Accionistas; por lo que en este caso la inoponibilidad no tendría sentido.

Sobre los dos supuestos anteriores Paz-Ares (2003) señala que en la doctrina existen una controversia sobre la validez de los contratos parasocietarios frente a la sociedad en relación a los pactos para impugnar juntas; sin embargo, la jurisprudencia española ha ido reconociendo paulatinamente que los pactos parasociales son oponibles a la sociedad cuando todos los socios que forman 
parte de él, asimismo para explicar este planteamiento cita algunos casos que han sido resuelto por los tribunales:

Caso Munaka: Cuatro accionistas de Munaka acuerdan mediante pacto estraestatutario reducir el capital y posteriormente disolver la sociedad. Dos meses más tarde por decisión mayoritaria la Junta General decide ampliar el capital social, omitiendo la reducción, uno de los socios se opone a la decisión tomada en Junta y se fundamenta en el pacto acordado por todos los socios, alegando que es contrario al interés social. El tribunal decide anular el acuerdo de Junta y le otorga validez al pacto parasocial, declarándola exigible frente a la sociedad, por ser un acuerdo de Junta Universal informal, al ser un acuerdo societario que vincula a la sociedad y tiene fuerza de ley según el Art. 1261 del Código Civil Español (Sentencia del TS de 26 de febrero de 1991 y del 10 de febrero de 1992).

Caso Hotel Atlantis Playa. Un socio dueño del 100\% de las acciones, reconoce mediante pacto privado que el $13 \%$ del capital le corresponde a otra persona. En los libros de la sociedad aparece únicamente registrado el socio único, éste convoca a una Junta General en la que comparece únicamente "el socio único", en dicha Junta se acuerdan: modificar los estatutos, nombramiento de gerente, etc. Posteriormente, los acuerdos son impugnados por el titular del 13\% del capital, alegando que el acuerdo de Junta contraviene el Art. 14 de los estatutos, señalando que se requieren como mínimo dos socios para la toma de los acuerdos, aunque en un solo socio se reúna la mayoría de las acciones. E1 Tribunal Supremo estima que los pactos privados son oponibles a la sociedad cuando ésta no pueda considerarse, en atención a la realidad de sus socios, un tercero ajeno e independiente. Existiendo en este caso una desestimación de la personalidad jurídica con el fin de evitar que esa ficción legal perjudique intereses privados o públicos (Sentencia del TS del 24 de septiembre de 1987).

Caso Promociones Keos. El accionista único de la sociedad, constituye una prenda sobre la totalidad de las acciones, señalando que el derecho al voto le correspondería al deudor pignoraticio, contrario a lo establecido en los estatutos de la sociedad en la que se establece que el acreedor pignoraticio tendrá derecho al voto. En este sentido, el acreedor celebra una Junta General de Accionista, adoptando una serien de acuerdos que el deudor prendario estima lesivos para sus intereses. El Registrador niega la inscripción de la Junta, aduciendo actuación de mala fe por parte del acreedor pignoraticio, decisión confirmada por la Dirección General de Registros. Considera abusiva la actuación del acreedor por vulnerar frontalmente el compromiso contractual adoptado; es decir, reconocer que los derechos de votos deberían seguir ostentándose por 
el deudor, existe un incumplimiento contractual con grave detrimento para los propietarios de las acciones gravadas que ven limitada su facultad. En este caso se rompe la regla de la inoponibilidad (Resolución de la Dirección General de Registros y del Notario-RDGRN del 26 de octubre de 1989).

- Puede ser cuando los socios han pactado según el derecho común, un derecho especial para un socio, en la cual, éste tendrá derecho a percibir parte de los dividendos de los socios denominada "cesión de derechos al dividendo", si la cesión es notificada a la sociedad, el socio cesionario tendrá derecho a reclamar a la sociedad.

Agrega Paz-Ares (2003) que la excepción a la regla de la inoponibilidad es aplicable a los pactos entre socios, no entre el consejo de administración, porque no existe identidad de voluntades entre socios y sociedad (Paz-Ares, 2003).

d) El objeto del contrato parasocietario. Recae en el interés de los accionistas respecto a la sociedad de la cual son socios. Es decir, los socios se obligan a realizar ciertas conductas, pueden consistir en una obligación de hacer, en donde se comprometen a ejecutar ciertos actos en función al cumplimiento de la voluntad manifestada de manera unánime. El interés es dirigido a surtir efecto a lo interno de la sociedad, no debe ser oponible a la sociedad como ya quedó expresado, lo que significa que el convenio parasocietario no debe ir en contra de la ley, la moral y el orden público (Art. 2437 Código Civil). La buena fe, como lo expresa Alterini (1999), deberá ser subjetiva y objetiva; subjetiva, por cuanto los socios al manifestar su interés, deberán actuar conforme a derecho y objetiva por que la decisión expresada en el contrato parasocietario deberá generar confianza al ser ejecutada por el socio o tercero.

e) Son actos colectivos. Varias personas -socios- tienen un interés común de obtener un fin concreto. Presentándose en este caso varias características identificadas por Alterini en su libro sobre Los Contratos Civiles, Comerciales y de Consumo de 1999, señalando que el acto colectivo es: colegiado, por que expresa una voluntad colectiva; proviene de una comunidad organizada de sujetos; es adoptada por una deliberación; se considera como una voluntad común expresada por la mayoría.

f) Los contratos parasocietarios son accesorios. Es un contrato ligado al contrato principal. Es accesorio porque para su existencia es preciso de previo el contrato social, de modo que al no haber un contrato social el pacto parasocial carece de sentido y no tendría validez (Art. 1877 Código Civil). 


\section{Reconocimiento legal de los contratos parasocietarios}

\section{a) Perú}

E1 Derecho peruano reconoce la figura del contrato parasocietario con énfasis "el sindicato de acciones" según el Art. 8 de la Ley General de Sociedades No. 266787 del 19 de noviembre de 1997:

Artículo 8.- Convenios entre socios o entre éstos y terceros. Son válidos ante la sociedad y le son exigibles en todo cuanto le sea concerniente, los convenios entre socios o entre éstos y terceros, a partir del momento en que le sean debidamente comunicados.

Si hubiera contradicción entre alguna estipulación de dichos convenios y el pacto social o el estatuto, prevalecerán estos últimos, sin perjuicio de la relación que pudiera establecer el convenio entre quienes lo celebraron.

El artículo citado condiciona la validez de los pactos a la comunicación que hagan los suscriptores del acto a la sociedad. Asimismo, los contratos societarios serán siempre superiores a los sindicatos de acciones y dichos convenios serán siempre respetados entre socios, entre éstos y terceros, lo que significa que una sociedad no podría inscribir una transferencia de acciones, si su vendedor incumplió las estipulaciones del pacto social, porque debe cumplir el derecho de preferencia a los otros socios. (Mosquera Alcocer, 2009; Gutiérrez Camacho, 1999; \& Castillo Chaves, 1998).

Otro hecho relevante en la que el Tribunal Registral del Perú se ha pronunciado, es que no debe confundirse la creación de un sindicato con la creación de una sociedad, según Resolución No. 055-2002-SUNARP-TR-L, los convenios de sindicación referidos en los Arts. 8, 55 y 92 de la Ley General de Sociedades no pueden constituir otra persona jurídica independiente a la sociedad de la cual son accionistas los sindicados.

\section{b) Argentina}

Desde el punto de vista de la jurisprudencia Argentina los pactos parasocietarios han tenido reconocimiento legal, en especial la figura de los sindicatos de acciones. Por su parte Fernando Mascheroni y Roberto Munguillo, citados por Walter Gutiérrez (1998), señalan que los sindicatos de acciones tuvo dos momentos; primero con Ley de Sociedades Comerciales No. 19.550 y el segundo posterior a la misma. El Código de Comercio Argentina en su Art. 358 derogado por Ley 
No. 19.550 se refería al caso de aquellos accionistas que representaban el 25\% del capital social y éstos se encuentren en un país extranjero, podían nombrar un mandatario para que los representaran en Asamblea General; concluyen los autores, que este artículo daba lugar a constituir un sindicato para ejercer de modo colectivo sus derechos, siendo una disposición criticada por ser discriminatoria frente a los accionistas nacionales, llegándose a sostener como inconstitucional. Posteriormente con la Ley No. 19.550 se omitieron la sindicación de acciones, la justificación fue porque este tipo de contrato no corresponde al régimen legal de las sociedades mercantiles. Por otra parte con la Ley y 22.903 y el fallo de la Corte Provincial de Buenos Aires del 22 de septiembre de 1982, reconoció los sindicatos de mando, al señalar que en el Derecho Argentino son aceptados y además establecen que mientras no se hayan producido situaciones patológicas que atente el interés social, en las cuales perjudique a otros accionistas, entonces no existe hipótesis de conflicto entre el objeto y el fin de los grupos sindicados.

\section{c) Brasil}

La ley de Sociedades por Acciones de Brasil (6404/76, Art. 118), reconoce los sindicatos de acciones solamente en el caso de compra y venta de acciones, derecho de preferencia y/o derecho de voto, pero exige al mismo tiempo que dicho pacto se registre en el libro de la sociedad. La ley contempla, que las acciones sindicadas no pueden ser negociadas en mercados de valores (Mosquera Alcocer, 2009).

\section{d) Chile}

En la Ley de Sociedades Anónimas (No.18.046, Art.64), no regula expresamente los pactos parasocietarios; sin embargo, establecen la posibilidad de autorizar un representante en la Junta General de Socios, sin fijar límites o cantidades de votos. En cambio la Ley de Mercado de Valores (No. 18.045, Arts. 98, 99), reconoce este tipo de pactos al señalar:

...La convención entre dos o más personas que participen simultáneamente en la propiedad de una sociedad, directamente o a través de otras personas naturales o jurídicas controladas, mediante la cual se comprometen a participar con idéntico interés en la gestión de la sociedad u obtener el control de la misma.

Se presumirá que existe tal acuerdo entre las siguientes personas: entre representantes y representados, entre una persona y su cónyuge o sus parientes hasta el segundo grado de consanguinidad o afinidad, entre 
entidades pertenecientes a un mismo grupo empresarial, y entre una sociedad y su controlador o cada uno de sus miembros.

Igualmente, el Art. 99 establece los efectos del convenio cuando un grupo de personas tienen un acuerdo de actuación conjunta controlada directamente al menos el $25 \%$ del capital con derecho de voto de la sociedad.

\section{e) Uruguay}

La Ley de Sociedades Comerciales No 16.060 en el art. 331 regula la sindicación de accionista:

Artículo 331. (Convenios de sindicación de accionistas).- Serán legítimos los convenios de accionistas sobre compra y venta de sus acciones, ejercicio de los derechos de preferencia y de voto o cualquier otro objeto lícito.

Los accionistas contratantes podrán ejercer todos sus derechos y acciones legales para el cumplimiento debido de las obligaciones asumidas y frente a quienes resulten comprometidos para la debida ejecución del convenio.

Estos convenios no tendrán efecto frente a terceros excepto cuando:

- Se entregue a la sociedad un ejemplar con las firmas certificadas

- Se incorpore un ejemplar al legajo de la sociedad.

- Se anote en los títulos accionistas o se haga constar en el libro de Registro de Acciones Escriturales. Cumplidos estos requisitos, las acciones respectivas no podrán ser negociadas en Bolsa.

Tratándose de sociedades abiertas, el órgano de administración informará a cada asamblea ordinaria sobre la política de capitalización de ganancias y distribución de dividendos que resulte de los convenios depositados en la sociedad. En ningún caso los convenios de sindicación de acciones podrán ser invocados para eximir a los accionistas de sus responsabilidades en el ejercicio del derecho de voto.

Los convenios de sindicación de acciones tendrán una vigencia máxima de cinco años, sin perjuicio de que las partes acuerden la prórroga tácita o automática de su plazo. 
Esta norma inspirada en el proyecto de sociedad anónima europeo y la Ley de Sociedades Anónimas de Brasil, otorga eficacia jurídica a los pactos parasocietarios y hace énfasis en la sindicación de acciones, permitiendo otros pactos en torno a la licitud del objeto y señalando un tiempo de vigencia de cinco años (Mosquera Alcocer, 2009).

\section{f) Europa}

La tendencia en los países europeos ha sido otorgarle validez y eficacia a los acuerdos parasocietarios, en especial la doctrina y la jurisprudencia ha jugado un papel importante en este contexto, a continuación expondré los países que regulan este contrato:

\section{g) Francia}

Mosquero Alcocer (2009) citando a Sánchez González, expresa que la ley de 1876 y la jurisprudencia de la época, desconocía los convenios sobre el derecho de voto, siempre que atentara gravemente contra el ejercicio del derecho, es decir, la prohibición no era absoluta. Posteriormente en 1933 el decreto ley de 1937 modificó la validez de estos convenios declarándolos nulos y sin efectos, cuando dichos pactos atentaran contra el libre ejercicio del derecho al voto en las Juntas Generales. En 1966 la ley sobre sociedades comerciales, derogó todas las materias reguladas sobre los convenios, dejando bajo la valoración de los tribunales la apreciación que de ellos hagan los tribunales. Posteriormente en 1966 el derecho francés evolucionó las convenciones de voto, señalando que los pactos de sindicación han de ser lícitos, en cuanto, no supriman totalmente el derecho del accionista de participar en decisiones sociales, como aquellas que no sean contrarias al interés social, así como los que estén exentos de cualquier visto de fraude. Fue precisamente en el año 1985 que se reconoce de forma expresa la validez de las convención es de voto (Mosquera Alcocer, 2009).

\section{h) España}

En 1951 la ley de sociedades en su Art. 60, reconoce que todo accionista puede ser representado, siempre que sea por escrito y en su carácter especial en cada junta, limitándose en gran medida los convenios de sindicación. Posteriormente en el año 1989 según el Real Decreto 1564/89 Art. 7, reconocen los acuerdos de sindicación, siempre y cuando sean comunicados (Mosquera Alcocer, 2009). Posteriormente el 2 de julio de 2010 según Real Decreto 1/2010, la nueva Ley de Sociedades de Capital en los artículos 530 al 535 regula los pactos para sociales de las sociedades cotizadas, manteniendo el mismo requisito de 
comunicación, pero agrega que además de ser notificada a la sociedad, también debe hacerlo a la Comisión Nacional de la Cámara de Valores. La nueva ley que establece las formalidades para la comunicación, requiriendo que el acuerdo deberá depositarse en el Registro Mercantil. Asimismo incorpora un artículo de dispensa señalando que cuando la publicidad pueda ocasionar un grave daño a la sociedad, la Comisión Nacional del Mercado de Valores, a solicitud de los interesados, podrá acordar, mediante resolución motivada, que no se dé publicidad alguna a un pacto parasocial que le haya sido comunicado, o a parte de él, y dispensar de la comunicación de dicho pacto a la propia sociedad, del depósito en el Registro Mercantil del documento en que conste y de la publicación como hecho relevante, determinando el tiempo en que puede mantenerse en secreto entre los interesados.

\section{i) Italia}

El estudio de los sindicatos de acciones ha tenido mucha importancia, en 1914 Vivante desarrolló el tema, lográndose posteriormente un proyecto legislativo que en su Art. 215 declaró nulo un convenio que vinculase la libertad de voto. Posteriormente, en el proyecto de 1926 se estableció la nulidad que vinculase la libertad del voto; sin embargo, se les podía conceder a los gerentes la facultad de ejercer el derecho al voto, siempre que no fuere a un plazo de 4 años. Luego en 1940 en el proyecto ministerial del Código de Comercio se señaló que los convenios por los que los accionistas confieren a otro socio el derecho de ejercer los derechos inherentes a la acción, debían ser probadas documentalmente y no podrán tener una duración de cinco años. $\mathrm{Al}$ aprobarse el proyecto desaparecen todas las normas que figuraban en los proyectos dejando en manos de los tribunales la emisión de una decisión frente al caso concreto (Mosquera Alcocer, 2009).

\section{Derecho germánico y anglosajón}

Rossi citado por Santiago Mosquera Alcocer (2009) señala que en este sistema la validez y aceptación de los convenios, tanto en Alemania como en los países anglosajones se deriva del principio generalizado de la libre cesibilidad del derecho de voto denominado property right.

\section{- Alemania}

En 1937 los convenios de sindicación eran plenamente válidos, situación que varía a partir de 1966 en la que por medio de ley se incorpora una disposición que restringe la licitud de estos convenios, con el propósito de que los Bancos, 
depositarios de estos pactos gobernaran la sociedad por encima de los órganos. Actualmente la figura de sindicación es totalmente admitida y válida por casi toda la doctrina y la jurisprudencia, pero niega la validez del acuerdo cuando sean contrario a los estatutos, afecten los principios generales del derecho y cuando implique abuso de derecho (Mosquera Alcocer, 2009).

En el Derecho Anglosajón existen dos instituciones comunes denominados voting trusts y el voting agreement. El Voting trust los accionistas quedan en una situación similar a la del nudo propietario, porque el capital sigue siendo de los accionistas, pero el ejercicio al voto que nace de la acción queda en fideicomiso.

Mosquero Alcocer (2009) citando a Rossi define los voting trust de la siguiente manera:

... La transmisión de las acciones que se sindican a un trustee para que éste ejerza dentro de la coporation el voto que emana de la tenencia de las acciones cuya titularidad ejerce el trustee. Los accionistas quedan en similitud de situación a la del nudo propietario, pues si bien el capital accionario trustificado les pertenece, el ejercicio del derecho de voto y la tendencia material y la titularidad de los valores pasa por lo general al trustee o fideicomisario, quien será la única persona reconocida como accionista por la corporation. A cambio de las acciones trustificadas, el fideicomisario o trustee emite un certificado -voting trustcertifícateque no tiene validez frente a la sociedad, pero que representa su porción en las acciones sindicadas (p. 23).

Los voting trusts están previstos en Model Business Coporation Act que surgió en 1950 y fue adoptado por varios Estados de la unión Americana, ésta insporó a varias leyes estatales, sin embargo, muchos de estos Estados que han regulado los voting trusts lo han limitado a cinco años.

Los voting agreement, condicionanel voto a los integrantes del pool,este sistema es más parecido al utilizado en el sistema latinoamericano, tiene como objeto obtener cierto control de la compañía, con el objeto de preservar el status quo. Son acuerdos confidenciales, que no tienen la obligación de notificar a la compañía, ni registrarla en el libro. 


\section{Estatuto de la Sociedad Anónima Europea}

E1 8 de octubre de 2001 empezó a regir el Estatuto de la Sociedad Anónima, este instrumento no tiene norma que regule los acuerdos de sindicación de acciones, como lo tenía el proyecto original. Dicho proyecto señalaba que los acuerdos de sindicación de acciones debían cumplir dos requisitos fundamentales; el primero, consiste, en comunicar a la sociedad para que surtiera efectos, declarando nulo los votos emitidos posteriores a la notificación y el segundo requisito, consistía en identificar a los sindicatarios y la cantidad de acciones, señalando el plazo de vencimiento del convenio de sindicación.

\section{Excursus sobre las principales tendencias y aportes del Derecho Comparado}

Las legislaciones europeas que se han ocupado en la actualidad del estudio de la sindicación de acciones, se han limitado en establecer hipótesis de nulidad de estos pactos, lo cual quiere decir, que tácitamente han admitido la legitimidad de los mismos. Rossi citado por Mosquero Alcocer (2009), señala como ejemplos: la legislación Belga, el Código Portugués de 1986, Holanda, Suiza.

La legislación peruana constituye uno de los sistemas más completo respecto a los contratos parasocietarios, en particular el sindicato de acciones, si bien nuestro ordenamiento no tiene un artículo similar a este precepto señalado, en el que expresamente se reconoce la validez de este tipo de contrato, no quiere decir, que en el sistema nicaragüense se niegue la validez de dichos acuerdos. Asimismo, el reconocimiento de los acuerdos parasocietarios tienen su fundamento en la autonomía de la voluntad y en la libertad de contratación, destacándose el artículo 32 de la Constitución Política que es el sustento del principio, al señalar que "ninguna persona está obligada a hacer lo que la ley no mande, ni impedida de hacer lo que ella no prohíbe". Los Arts. 1836, 2439, 2479 del Código Civil, disponen que las obligaciones que nacen de los contratos, tienen fuerza de ley entre las partes y debe cumplirse al tenor de los mismos; por lo tanto, los pactos parasocietarios constituyen ley entre las partes contratantes.

Otro aspecto relevante, destacado en la legislación peruana, es en relación a la jerarquía de los acuerdos, sobre este particular, sobresalen los estatutos y reglamentos porque están por encima de los acuerdos parasocietarios; no puede, un acuerdo de este tipo oponerse a lo dispuesto en dichos contratos. Situación similar ocurre en el mismo ámbito dentro del esquema societario de la sociedad anónima de Nicaragua, sobre los acuerdos de los socios en Junta General de Accionista, nuestro sistema expresa que ningún acuerdo emitido en junta puede estar en oposición a la ley y estatutos, siendo objeto de protesta por 
parte de cualquiera de los socios según lo dispone el artículo 261 del Código de Comercio de Nicaragua. En mi opinión, aunque se refiere a los acuerdos de Junta, esta disposición es claramente aplicable a los pactos parasacietarios, por analogía. El reconocimientos de estos acuerdos, como si fueran acuerdos emitidos en Junta lo podemos comprobar en la jurisprudencia española citada anteriormente Español (Sentencia del TE de 26 de febrero de 1991 y del 10 de febrero de 1992)sobre el caso Munuka que ejemplifica de forma paradigmática el recurso a la ficción de la existencia de una Junta Universal, otorgándole fuerza de ley al contrato celebrado entre los socios.

Otro punto de reflexión sobre los contratos parasocietarios regulados en la legislación peruana, es en relación a la comunicación de dichos instrumento a la sociedad, generalmente esto pactos se mantienen en secreto, pero a pesar de su secretividad, la legislación peruana exige que debe ser comunicado a la sociedad, para su validez. Aunque los pactos de este tipo no son parte de los estatutos, pero su contenido se refieren a la gestión o decisión interna o externa de la sociedad. Por otra parte, nuestro sistema legal, al no referirse a los contratos parasocietarios, tampoco se refiere a la comunicación como requisito de validez, simplemente queda dentro del ámbito privado entre los socios o entre las partes del contrato. Los artículos 36, 37 del Código de Comercio Nicaragüense en ningún caso expresan la posibilidad de inscribir convenios de este tipo en los libros sociales, aunque nada impide que en los estatutos se pacte la posibilidad de inscribir los convenios de accionistas en el libro de Registro de Acciones que lleva la sociedad, otorgándole por este medio eficacia jurídica. Por otra parte la Ley No. 698 Ley General de Registro Público es bastante amplia al señalar en los considerandos I, II que la ley otorga seguridad jurídica a los agentes económicos mediante la inscripción y publicidad de los actos y contratos mercantiles. Asimismo, el Art. 156 numeral 8, describe que son objeto de inscripción en el Registro Mercantil los poderes que otorguen los comerciantes o empresarios, conforme a los Arts. 4 y 153 de la misma ley.

Otro aspecto relevante de la ley peruana, es que también reconoce los acuerdos entre socios y terceros, otorgándole eficacia jurídica, siempre que cumplan con los requisitos de comunicación y que no sean contrarios a los estatutos. En Nicaragua el Art. 131 del Código de Comercio, expresamente señala "La convención por la cual un prestamista de dinero estipulase participación en las ganancias, sin responder por las obligaciones del socio, es ilegal y nula. Es asimismo nula la estipulación de que el prestamista sin responsabilidad en las pérdidas, tendrá parte en las ganancias además de los intereses. Podrá, sin embargo, establecerse que en las utilidades líquidas se abone previamente un interés fijo o un capital preferido sobre los demás". Igualmente el Art. 3185 
del Código Civil dispone "...que no es permitido que los socios contraten en su propio nombre con terceros". En este caso, nuestra ley se refiere a lo pactado en el contrato social, no a los convenios entre socios y terceros que se dan de manera externa a la sociedad, pero se relaciona por cuanto, lo que no es válido dentro del pacto social, no es válido fuera del mismo, en otras palabras un convenio parasocietario en la que se pacte con terceros sobre el derecho económico de recibir las ganancias no es válido. Ciertamente, es una limitante, pero como se expuse anteriormente puede ser que entre el socio y el tercero se haya pactado una cesión de crédito conforme lo establecido en la legislación comercial y civil, siendo válido si se hace en dichos términos. Asimismo, lo anterior nos lleva a exponer lo señalado en el Art. 2220 del Código Civil sobre la simulación de los contratos, en este caso particular el Art. 2222 nos indica que son válidos siempre que no sean contrarios a ley y que no sea ilícito.

En el caso de la legislación chilena, señala el reconocimiento de un representante en la Junta; en este sentido, el accionista con derecho de asistencia puede hacerse representar en la Junta General por otra persona que no tiene por que ser accionista, esta representación, puede ser a una persona natural o jurídica. El documento en que conste el poder deberá contener o llevar anejo el orden día, así como la solicitud de instrucciones para el derecho al voto y la indicación del sentido en que votará el representante, pero podrá votar en diversos sentido, cuando corra el riesgo de perjudicar los intereses del representado, debe informar inmediatamente a su representado o a quienes representa, como es el caso de un sindicato de acciones. Nuestro sistema, no regula la forma en que puede consistir el mandato de este tipo, aunque se aplican por lógica jurídica las disposiciones sobre Código Civil en relación a las reglas del mandato, es particular el mandato especial, por cuanto son aplicables las disposiciones 3293, 3310, 3311.

En relación a la legislación de Uruguay, la ley fue más precisa al reconocer expresamente el sindicato de acciones como principal contrato parasocietario, precisando que el convenio se refiera a la compraventa de acciones, derecho de preferencia y cualquier otro objeto lícito. Asimismo, precisa la formalidad que debe cumplirse para ser comunicada a la sociedad, señalando que debe ser presentada con las firmas certificadas y deben ser presentados en el libro de acciones; por último, señala una vigencia de cinco años. Resulta ser una posición rígida en relación a la libre actuación de los socios, pero es necesaria; por cuanto, establece una especie de control externo, frente a la conducta de los socios. Asimismo, la legislación uruguaya establece un límite en el tiempo. Cabe aclarar, nuevamente que en el caso nicaragüense, los artículos 36, 37 sobre el libro de actas y libro de acciones que llevan las sociedades anónimas, no establecen que se podrá anotar o inscribir en dichos libros éstos tipos de acuerdos extra societarios. 
Por lo tanto, se puede concluir, que en nuestro caso no requiere anotación en los libros de la sociedad, manteniéndose en secreto. Aunque en base a libertad de contratación (Art. 32 Constitución Política) los socios pueden establecer en el contrato social la posibilidad de inscribirse en el libro respectivo los acuerdo de sindicatos de socios y también pueden señalar las formalidades respectivas.

Por otra parte, Francia, precisa la legalidad de los acuerdos parasocietarios, señalando que deben ser lícitos, en cuanto no supriman derechos de los accionistas. Cabe señalar que pesar de que nuestro sistema no precisa sobre la legalidad de los contratos parasocietario, pero se refiere a los derechos de los accionistas, describiendo que al accionista no se le puede prohibir ciertos derechos irrenunciables, entre los cuales tenemos:

a) Un grupo de accionistas que representen la vigésima parte del capital social podrán solicitar a la Junta Directiva que se convoque a una Junta General Extraordinaria. Este derecho es irrenunciable, por lo que si la Junta Directiva no procede conforme a lo solicitado, podrán solicitarla al juez competente (Arts. 251,252 Código de Comercio). Ningún pacto extraestatutario podrá ni siquiera limitar este derecho.

b) Cualquier accionista independiente del número de sus acciones, podrá impugnar los acuerdos sociales, cuando sean contrarias a la ley y estatutos (Arts. 261 Código de Comercio). No puede un acuerdo para societarios suprimir este derecho.

c) Pactos de disposición del capital social para fines distintos a los convenidos en el contrato social. Ejemplo: la emisión de acciones por debajo de su valor nominal (Arts. 124.8 y $224 \mathrm{Cc}$ ); disponer de la reserva legal fines distintos (Art. 124, $249 \mathrm{Cc}$ ); pagar dividendos a los accionistas cuando no sean con beneficios realmente obtenidos (Art. $259 \mathrm{Cc}$ ).

En el caso de la legislación española, como ya quedó indicado y comparándolo con lo señalado en la legislación peruana y uruguaya, requieren que sea comunicado a la sociedad. En el mismo sentido y de acuerdo a la legislación Argentina, aunque no existe normativa actual en Italia que regula los contratos parasocietarios, tiene el mismo tratamiento que en nuestro caso, es decir, se rige por la autonomía privada.

En relación al derecho anglosajón, posteriormente analizaré este tema como caso figuras afines al contrato parasocietario. 


\section{Sindicación de acciones}

\subsection{Concepto y alcance}

El sindicato de acciones, es el contrato parasocietario de mayor frecuencia en la práctica de las sociedades anónimas. Son relaciones jurídicas que tienen por objeto votar en los órganos de la sociedad afectada o abstenerse en hacerlo. Este acuerdo entre accionistas tiene como finalidad comprometer por anticipado la forma de votar en las juntas de accionistas u órganos de administración. Los socios delegan en un accionista o en un representante denominado síndico la confianza para que lleve a cabo lo acordado por los sindicados. Este sistema de sindicación de acciones puede ser empleado por accionistas mayoritarios o minoritarios, siendo un sistema cerrado, por tipo de decisión que se toma a lo interno del sindicato de acciones. Se caracteriza por ser un contrato colectivo o plurilateral, con fines extrasocietarios (Quesnay Casusol, 2009; Sáez Lacave, 2007; Paz-Ares, 2003; Gutiérrez Camacho, 1999; Caamacho, S.F; \& Castillo Chaves, 1998).

De acuerdo a la definición anterior se puede destacar que los sindicatos de acciones presentan las siguientes características:

a) Es un acuerdo plurilateral, extrasocietario o parasocietario. Es un contrato al margen de la sociedad, subordinado a éste, no puede ser oponible a la sociedad, ni obliga a la misma.

b) Es atípico e innominado, no tiene una regulación propia en el ordenamiento jurídico nicaragüense.

c) El acuerdo origina una obligación de hacer.

d) Es un contrato de carácter secreto y lícito. Aunque en la legislación Peruana, Uruguaya, Española, quedó claro que debe ser comunicado a la sociedad para que surta efectos, en nuestro caso este requisito puede depender de lo establecido en el acta constitutiva y estatutos de la sociedad, de acuerdo al principio de libertad de contratación y autonomía de la voluntad.

e) No requiere aporte de capital, porque su fin no es el de producir, ni intercambiar bienes, ni servicios. Constituye esta característica una diferencia de las asociaciones en participación y momentáneas (Arts.329 $\mathrm{y}$ siguiente del $\mathrm{Cc}$ ), en la que pueden haber aportes de bienes o servicios. 
f) Tiene como finalidad hacer una masa de acciones sindicadas, sustituyendo las acciones dispersas por las acciones unitarias. Pueden ser sindicatos de mayoría accionario o de minoría.

g) Es un contrato informal, no requiere de forma o modalidades para que el sindicato se constituya. Siendo consensual, se perfecciona por el simple consentimiento.

h) Es temporal, aunque el sindicato de acciones no tiene tiempo definido en nuestro sistema, en cambio en otros sistemas tiene una vigencia de 3 a 10 años (Brasil: 10 años, Alemania: 10 años). Excepto, si se trata de la sindicación de acciones constituida como "fideicomiso de acciones" en la que sí existe un plazo y en caso de no pactarse no puede exceder de 30 años (Art. 48 de la Ley No. 741 "Ley sobre contrato de fideicomiso". Publicada en la Gaceta Diario Oficial No. 11 del 19 de enero de 2011, en lo sucesivo Ley 741/2011).

i) Tiene como objeto inmediato la votación a lo interno en los órganos sociales. La votación puede ser uniforme en un solo sentido, abstenerse de votar y votar en un sentido que favorezca a la mayoría o minoría, según el interés de los sindicados.

j) La votación en los órganos sociales puede ser personalmente o por medio de un representante.

k) El contrato confiere el control de las acciones.

1) El contrato de sindicación de votos, son acuerdos paralelos a la Junta General.

m) Los intereses de los sindicados no tienen que corresponder con los intereses de la sociedad, es decir, tienen por objeto responder a los intereses de quienes lo acuerdan.

n) Es un contrato accesorio al contrato social y estatutos.

En mi opinión el sindicato de acciones, es un acuerdo entre accionistas de una sociedad anónima con interés propio, celebrada paralelamente a los órganos de la sociedad, dirigido a producir efectos frente a la sociedad o a frente a terceros. Acuerdos que se toman por los mismos socios en su carácter personal o a través de un gestor irrevocable, quien depositará el voto pre-establecido en uno de los órganos. Este grupo de accionistas puede ser mayoritario o minoritario. 


\subsection{Naturaleza jurídica del sindicato de acciones}

La naturaleza de este tipo de contrato es muy discutida en la doctrina, por un lado se cree que se trata de una sociedad paralela a la que pertenecen los sindicados, por otro lado se dice que es una especie de sociedad irregular y otros consideran que se trata de un acuerdo de asociación, con características de contrato plurilateral y organizativo (Gutiérrez Camacho, 1999; Mosquero Alcocer, 2009; Simois Lapeyre, 2001; Uría, Menéndez 1999; Broseta Pont, 1990).

A continuación analizaré si los elementos que identifica la doctrina tienen fundamentación en el sistema nicaragüense:

\subsubsection{Es un contrato de prestaciones plurilaterales autónomas:}

Los autores Guzmán García \& Herrera Espinoza (2006), explican:

"Que siendo un concepto propuesto por la doctrina Italiana-siguiendo la discusión de la doctrina Alemana habida a fines del siglo diecinueve sobre la sociedad producto de un acto contractual, pretende destacar la importancia de la colaboración que pueden realizar varios sujetos a propósito del cumplimiento de un fin que redunda en beneficio de todos y cada uno" (p. 104).

Tullio Ascarelli citado por Guzmán \& Herrera (2006), expresa que en éstos contratos, las partes son titulares de derechos y obligaciones que cada una asumen no frente a la otra, sino frente a los demás, cada parte está ubicada como en un circulo. En este mismo sentido, el Dr. Iván Escobar Fornos (2000) define los contratos plurilaterales, señalando que en estos actos coinciden las voluntades para un mismo fin, en el exterior aparecen como una manifestación de voluntades unitarias, tiende a tutelar un interés similar para todos, no contrapuestos, sino iguales.

Guillermo A. Moglia Claps (2011) profesor de la Universidad de Salvador Argentina, define el contrato plurilateral como aquel cuyas prestaciones de las partes están dirigidas a la obtención de un fin común, que es la causa del contrato, en el que las partes tienen una misma e idéntica naturaleza jurídica, son cualitativamente iguales. A este contrato no se le concibe la ventaja propia a expensas de la otra parte. En el contrato plurilateral es compatible con la esencia del sinalagma. 
Expone Gutiérrez Camacho (1999), que primero se debe analizar que se trata de un contrato con prestaciones plurilaterales. En este sentido, el Código Civil Italiano define el contrato plurilateral en el Art. 1420 "En los contratos con más de dos partes, en el que los beneficios de cada uno están dirigidos a lograr un objetivo común, el vacío que afecta a la unión de un solo partido no se preocupa por el contrato, salvo que debe participar, de acuerdo con la circunstancias, se considera esencial”.

Según los criterios anotados se puede concluir, que los sindicatos de acciones son contratos plurilaterales, por cuanto participan dos o más sujetos como accionistas minoritarios o mayoritarios, que crean una especie de organización aunque no con personalidad jurídica, porque sus miembros persiguen un fin común por un tiempo determinado. En Nicaragua, a pesar de no existir una definición como en el Código Italiano, nuestro Código Civil reconoce esta clase de contratos según lo dispuesto en el artículo 3175 en el que define el contrato social, partiendo de los siguientes elementos:

- Es un contrato celebrado por varias partes.

- Las prestaciones tienen un fin común.

- Todas las partes manifiestan su voluntad en un mismo sentido.

Comparando las características de los contratos de sindicación de acciones como contrato parasocietario y los contratos plurilaterales a continuación presento un paralelismo entre ambas figuras, con el objeto de identificar los elementos que los caracterizan como tal:

a) Los contratos plurilaterales tiene un fin común, siendo éste fin el de los contratos de sindicación de acciones.

b) En los contratos plurilaterales participan dos o más partes, en el sindicato de acciones pueden ser dos o más accionistas mayoritario o minoritario.

c) En los contratos plurilaterales se crea una especie de organización; en los contratos de parasociales se crea una organización denominada sindicación;

d) En los contratos plurilaterales, las partes quedan libres de salir o entrar; en la sindicación de acciones, se presenta el mismo fenómeno, pero no es recomendable, por cuanto rompe el principio de confianza y lealtad que debe prevalecer en estos contratos. 
e) Las prestaciones originadas, no necesariamente son aportes de capital; en la sindicación de acciones, las prestaciones corresponden a los intereses societarios.

f) Los contratos plurilaterales, se crean para una vigencia determinada o no; en el contrato parasocietario o sindicación, establecen un plazo determinado.

g) En los contratos plurilaterales, el incumplimiento de una de las partes puede traer como consecuencia la resolución del contrato; en cambio, en los contratos de sindicación puede originar la resolución del contrato solamente en la parte que le incumbe.

h) El perfeccionamiento de los contratos plurilaterales y sindicación de acciones se produce de modo simultáneo.

i) Las prestaciones tienen un fin común; en los contratos de sindicación de acciones el interés es común entre sus miembros.

\subsubsection{Contrato asociativo}

Una vez expuesto que la sindicación de acciones es un contrato de prestaciones plurilaterales autónomas, ahora corresponde el análisis delcontrato asociativo: El Código de Comercio de Nicaragua no define el contrato asociativo como lo hacen otras legislaciones, por ejemplo la Ley de Sociedades Comerciales del Perú del primero de enero del año 1998, en el Art. 438 "Se considera contrato asociativo aquel que crea y regula relaciones de participación e integración en negocios o empresas determinadas, en interés común de los intervinientes. El contrato asociativo no genera una persona jurídica, debe constar por escrito y no está sujeto a inscripción en el Registro". Este tipo de contrato asociativo no crea una nueva persona jurídica, ni genera un patrimonio autónomo. Por lo tanto, el contrato asociativo de sindicación de acciones, es un contrato parasocial en el sentido que se estipulan al margen del contrato social y de la sociedad, en algunos casos puede integrar el pacto social y estatutos, aunque se trate de un acto jurídico distinto. El objeto inmediato de este contrato es influir en el funcionamiento de la sociedad desde afuera (Gutiérrez Camacho, 1999).

Este contrato asociativo, persigue como objeto influir en la sociedad desde afuera. Visto como acto colectivo en donde varias personas tienen un interés común. A la luz de nuestro sistema el Art. 331 del Código de Comercio de Nicaragua reconoce que los contratos de asociación en participación, persiguen un beneficio para todos los que lo integran, pero según el Art. 330 Cc cada 
integrante responde de sus actuaciones frente a terceros, en este caso frente a la sociedad de la que son socios. Asimismo, el Art. $332 \mathrm{Cc}$ reafirma el principio de autonomía privada de los contratos parasocietarios, al señalar que este contrato se regirá por lo convenido entre las partes. No debe confundirse a los contratos asociativos con la mal llamada sociedad paralela, por cuanto las asociaciones no crean una nueva sociedad (Art. 331 in fine Cc). En relación a la formalidad para su creación, el Código de Comercio en el artículo 333 expresa que no está sometida a ninguna formalidad para su formación y por consiguiente puede probarse por cualquier medio señalado en el mismo Código de Comercio, en este caso se refiere al Art. $111 \mathrm{Cc}$.

\subsubsection{Es un contrato accesorio al contrato social}

Es un contrato accesorio al contrato social, porque no es parte de éste y vive a la sombra del mismo, no obstante su accesoriedad, debe delimitarse al quedar dentro del pacto social. Sin embargo, en algunos sistemas que reconocen los contratos parasocietarios como es el caso de la legislación peruana, se exige que sean debidamente comunicadas a la sociedad (Gutiérrez Camacho, 1999).

En este sentido, José Sánchez González (1991), expresa que la accesoriedad presenta como consecuencia de su relación los siguientes efectos:
a) La nulidad del contrato societario provoca la nulidad del contrato de sindicación.

b) El acuerdo de sindicación no entra en vigencia mientras no esté vigente el de la sociedad.

c) Si no tiene fecha el contrato de sindicación, entonces es el de la sociedad.

d) El contrato de sindicación no debe contraponerse con las normas imperativas de la sociedad.

\subsubsection{Es un contrato para societario}

Parasocietario, porque es un acuerdo emitido por una mayoría o minoría de socios que representan un porcentaje del capital social. Nace la autonomía privada, siendo un contrato que se mantiene en secreto en el caso de Nicaragua, excepto que se trate de un contrato de fideicomiso de acciones que como desarrollaré a continuación es una figura análoga a la reconocida en el derecho anglosajón como voting trusts. 


\subsubsection{Es un contrato de empresas}

Es un contrato destinado a las empresas, en particular a las sociedades anónimas, porque se trata de las acciones más que de las personas. Es decir, debe existir de previo una entidad mercantil con personalidad jurídica. Por esa razón, de acuerdo al artículo 1, 2, 118, 202 del Código de Comercio adquiere una naturaleza mercantil. Cabe aclarar que el contrato de sindicación no pertenece al derecho común y que sólo supletoriamente se regulará por las normas del derecho civil, en especial las normas de las obligaciones y teoría general de los contratos (Arts. 2, 3, $4 \mathrm{Cc})$.

En relación a la sociedad paralela. No es el caso de la sindicación de acciones, puesto que no adquiere personalidad jurídica. Las sociedades paralelas tienen una finalidad distinta, éstas pueden crearse con motivos estratégicos para subdividir el patrimonio empresarial y desviar la atención entre dos formas jurídicas dependientes. Asimismo, como lo indica el jurista Italiano Oppo citado por Gutiérrez Camacho (1999), que al lado del contrato social existía un conjunto de contratos, que pese a no ser parte de él y por quedar fuera del ordenamiento social, viven de la sombra a cuyo desenvolvimiento están vinculados. De ahí su carácter accesorio, la sociedad es un tercero en este contrato, pues no es parte de él.

En nuestra consideración,compartiendo lo señalado por los autores y según los planteamientos legales, el contrato de sindicación de acciones es un contrato parasocietario con características asociativas propias, plurilaterales, accesorio, organizativo destinado a las empresas, de naturaleza mercantil.

\section{Figuras afines al contrato de sindicación de acciones: Voting-agreement y voting- trust}

\subsection{Voting-trusts}

Esta figura tiene un gran parecido con los contratos de sindicación. En Estados Unidos es frecuente a través del voting trusts, consiste en que se le transmite acciones sindicadas a un trustee, para que ejerza el derecho político al voto, con titularidad propia. Esta forma adoptada por el sistema de Estados Unidos consiste en otorgarle poder a un tercero para que ejerza el derecho al voto, mediante una carta poder que entrega él o los accionistas a fin de que el instituido vote en la asamblea. Como una forma de agrupar acciones nació y se desarrolló el voting trust, que tiene por objeto lograr la permanencia del grupo de control en el manejo de la sociedad y evitar que los accionistas ejerzan 
el voting power que les permitiera modificar la composición de los órganos de administración. Los accionistas que ingresan a este sistema transfieren la propiedad de las acciones a un trustee, éste emite un certificado con los que se demuestra el derecho patrimonial de los accionistas. El trustee no reviste de la calidad de accionista es un tercero extraño de la sociedad (Gutiérrez Camacho, 1999 \& Mata y Trejo, 1980).

Carlos A. Molina Sandoval (2005), señala que el fideicomiso puede ser utilizado:

a) Para asegurar el cumplimiento de las restricciones voluntarias a las transmisiones de acciones (bloqueo) o ejecución de las decisiones de gobierno social (mando).

b) Para resolver situaciones de empate en sociedades en que ningún accionista o grupo de accionistas tienen la posibilidad de formar la voluntad de la sociedad.

c) Como herramienta para asegurar la eficacia de un derecho de opción de compra, para acelerar y simplificar el closing de una compraventa de acciones.

d) Como instrumento flexible para la formación y managment de un portafolio individual de inversores en acciones.

Esta figura permite centralizar el ejercicio de los derechos de los accionistas y luego a la modalidad y estructura del fideicomiso. Este sistema se encuentra aislado patrimonialmente de las contingencias patrimoniales personales del accionista fiduciante y del mismo fiduciario.

Comparando el voting trust con el fideicomiso Molina Sandoval (2005) expone que el fideicomiso de acciones funciona de la siguiente manera: Uno o más accionistas (fiduciante) celebra un contrato de fideicomiso sobre las acciones de una sociedad, designando como fiduciario a una persona distinta, pudiendo ser uno de los socios. El fiduciario ejercerá los derechos sociales, transferido por medio del contrato (derecho al voto, participación, elección de administrador, requerir convocatoria de asamblea, información, dividendo, etc.), con la obligación de transferir al termino el paquete accionario al fideicomisario.

Sobre el ejercicio de los el Derecho de los accionistas, en este tipo de contrato Molina Sandoval (2005) señala que en el caso del derecho al dividendo el fiduciante tiene derecho a percibir los beneficios, pero no podrá ejercer a título 
personal las acciones judiciales para cobrar el dividendo, porque para eso está legitimado el fiduciario. Aunque, también tiene derecho de ejercer este derecho el mismo fiduciante. En relación al derecho al voto, es una función primordial designada por el fiduciante al fiduciario, no se trata de un derecho reservado como sucede en el caso del usufructo, que permite al nudo propietario reservarse el derecho de voto, puesto que el fiduciante ha dejado de ser propietario del título y en su condición de fiduciante ha dejado de ser propietario del título. Pero la doctrina acepta que el fiduciario otorgue poder, siempre y cuando cumpla con los siguientes criterios: sea temporal; no se trate de fraude; no encubra una lisa y llana cesión del derecho a votar en las asambleas; se trate de una asamblea y no para todas; que sea otorgado en función al contrato de fideicomiso.

En relación al derecho de la información, este derecho es vital en la dinámica societaria, pudiendo ser ejercida por el fiduciario, el problema radica en que si el fiduciante puede ejercer este derecho, siendo factible, siempre y cuando haya incumplimiento de parte del fiduciario (Molina Sandoval, 2005).

Según expone Mata y Trejo (1980), el problema de la fiducia es que puede ser considerada como un contrato simulado con el objeto de lograr una cesión permanente del fiduciante al fiduciario. Otra complicación que expresa el autor es en relación a la quiebra del fiduciario, por cuanto, si tiene la propiedad plena de los acciones, integraría la masa activa concursal, el fiduciante podría alegar el enriquecimiento sin causa de los acreedores, pero resultaría incierto, porque éstos, estarían a su vez en condiciones de argumentar que otorgaron los créditos al fallido (fiduciario), en virtud de que consideraron o tuvieron conocimiento de que era propietario de las acciones transmitida fiduciariamente. Esto sería al contrario en el caso del fiduciante, siendo aplicables las normas concursales respecto a la quiebra de los contratos pre-existentes.

Desde el punto de vista de nuestro sistema jurídico nicaragüense, el voting trusts es una figura aplicable a los contratos de sindicación de acciones, por cuanto no encuentro ninguna norma que contradiga su uso en materia societaria. Dicho planteamiento se ve hoy reforzado por la reciente aprobación de la Ley sobre el Contrato de Fideicomiso No. 741 publicada en el Diario Oficial No. 11 del 19 enero de 2011, en los artículos 2,3 establecen que las personas podrán contratar toda clase de fideicomiso con fines lícitos de acuerdo a la Constitución Política del País y las leyes ordinarias. Asimismo, expone que tiene por objeto establecer cualquier tipo de fideicomiso, excepto los casos en que requiere ser ejercido de manera personal. En otras palabras, el voting trusts, es aplicable a nuestro caso, denominado contrato de fideicomiso de acciones. 
Es por tanto, un vehículo del sindicato de acciones pero que para su aplicación debe tomarse en consideración los siguientes criterios:

- Importa una verdadera transferencia dominical fiduciaria. Art. 5 de la Ley No. 741

- Puede utilizare para sindicatos de mando o de bloqueo de acciones o para tomar ciertas decisiones, temiendo que pueda producirse el incumplimiento por parte de algunos socios. Aunque el contenido de los derechos aún no queda claro en la ley No.741, pero el Art. 14 inciso $f$, establece el alcance de los derechos que puede ejercitar el fiduciario.

- Debe inscribirse en el registro del emisor. A diferencia de los otros tipos de sindicatos de acciones, el fideicomiso, establece como requisito de validez la inscripción en el Registro del emisor, es decir, en el libro de acciones (Art. $37 \mathrm{Cc}$ ). Este sería el único caso en que se equipararía a la legislación peruana y uruguaya porque requiere inscripción en la sociedad. Art. 9 inc c) Ley No. 741.

- El fiduciario debe actuar de acuerdo a lo pactado en el contrato. Art. 30 Ley No. 741.

- El contrato de fideicomiso tiene un plazo determinado de 30 años, excepto que las partes señalen un plazo más corto. Art. 48 inc b) Ley No. 741.

\subsection{Voting-agreement}

Es similar al sindicato de acciones, pero en este caso, no existe la figura del trustee. Según la Amercian Bar Association (2005), consiste en la puesta en común de los accionistas, dichos acuerdos no están sujetos a las normas relativas al voto de confianza. El único requisito es que esté escrito y firmado por todos los accionistas que participan, no están limitados un término específico como en el caso de vonting trust.

En relación a Voting-agreement, los tribunales se han visto frente a dos problemas: Los pactos contrarios al orden público y la validez frente a quienes pueden ser opuestos. En este orden de ideal el fallo Manson c. Curtis (Palmiter, 2009), señaló que no es ilegal ni contrario al orden público que dos o más accionistas se unan para decidir la política societaria o los directores a elegir. Este acuerdo 
puede ser de un grupo minoritario, pero mayoritario respecto al número de acciones. Los accionistas tienen derecho a unir intereses y utilizar sus derechos al voto de manera que aseguren el control de la sociedad. Por último, En Weil c. Beresth, la Corte entendió que los "voting agreements" no son inválidos "per se" bajo las reglas generales del common-Iaw.

La diferencia entre vointg-agreement y vonting trus, consiste en que en la primera no se presenta la figura del trustee (fideicomisario), manteniendo los socios sindicados la titularidad de sus acciones, obligados a votar según lo acordado en las Juntas Generales. Esta figura ha sido regulada en varios Estados de Estados Unidos, inspirada en el Art. 34 de la Model Business Corporation Act (Amercian Bar Asociation).

\section{Clases de sindicación de acciones}

En la doctrina y en la práctica societaria existe una gran variedad de clases de sindicaciones de acciones, en este trabajo expondré los más importantes, así como también señalaré la admisibilidad de cada uno en nuestro sistema:

\subsection{Sindicato de voto}

El derecho al voto constituye uno de los derechos políticos de mayor importancia en el seno de la sociedad, es definido como un derecho intangible del que no puede ser privado ningún socio (Art. $224 \mathrm{Cc}$ ), excepto en los casos previstos por el Código de Comercio como el señalado en el Art. 224 y $225 \mathrm{Cc}$ ) y que ha de atribuirse de forma rigurosamente proporcional, de conformidad al valor nominal de la acción (García Rendón, 1993 \& Uría-Menéndez, 1999).

Por su parte Vicent Chuliá (2004), establece que el voto es el principal derecho político, instrumental para gestionar la sociedad y obtener beneficios repartibles. El titular de la acción tiene derecho a emitir una declaración de voluntad por si sola-este es el caso de la Junta.

El derecho de voto del accionista no es un deber exigible a éste, ni una potestad en interés ajeno, por la cual, el voto es concedido al accionista exclusivamente para la protección del interés social (Matta y Trejo, 1980).

Pues bien, definido el derecho al voto, éste puede ser cedido en un contrato denominado sindicatos de acciones; en este contrato, los accionistas deciden votar en grupo de acuerdo a un interés determinado, puede ser un grupo de poder mayoritario, con intención de tomar u ocupar los puestos de dirección de 
la sociedad e influir en las decisiones de mayor importancia. Este tipo de contrato de sindicación de voto, se hace por medio de un contrato y los accionistas ceden el derecho de voto a un representante que puede ser un mandatario o pueden utilizar otra figura que persigue como finalidad darle cumplimiento a lo pactado (Sánchez Linde, 2008 \& Gutiérrez Camacho, 1999).

Tomando como base las definiciones anteriores puedo señalar que los sindicatos de acciones cumplen con las siguientes características:

a) Los socios agrupados aspiran gobernar la sociedad y ocupar los puestos de dirección. En este sentido, los socios deben coordinarse con su representante, pero pueden encontrarse situaciones en los cuales, el poder de decisión se encuentre diluido y anulado, debido a una falta de coordinación entre los socios. Por ejemplo: votar por separado al momento de elegir el directorio, de modo que ninguno de sus candidatos resultan electos. La agrupación de acciones, no es motivo de violación a la norma mercantil, todo lo contrario, nuestro Código de Comercio admite la agrupación de acciones, precisamente en el Art. 251 reconoce la posibilidad de que la vigésima parte del capital social puede pedir que se convoque a una Junta General Extraordinaria. En este caso, aunque el Código de Comercio no describe los contratos objeto de estudio, pero se presume que este artículo se refiere al mismo, en especial, al sindicato de acciones, que de previo debió reunir a un grupo de accionistas y juntar el capital social requerido para proceder a pedir o hacerlo ante un juez competente.

b) Tiene como finalidad tomar decisiones de importancia. Un ejemplo sería el acuerdo de un socio con un Banco, condicionado a la realización de ciertos actos de la sociedad, como podría ser no repartir dividendos en exceso de cierto límite, respetando las medidas de seguridad que deben garantizar la estabilidad del capital social de la sociedad; entonces los acuerdos en materia de voto, pueden permitir al socio asegurarse de que esas condiciones se cumplan.

c) El contrato de sindicación de acciones establece un programa que debe cumplirse. Estos convenios de votos, permiten lograr que las situaciones de diferencias de decisión se cumplan.

d) Los accionistas ceden su voto, siempre y cuando la decisión coincida con el acuerdo conjunto. Sánchez Linde (2008) y Paz-Ares (2003) señalan que el derecho al voto no es personalísimo, sino que se considera como 
derecho patrimonial. Por consiguiente el accionista se obliga a votar, dando instrucciones a un representante, en sentido determinado, o de no votar, a cambio de ventajas patrimoniales que le ofrecen los accionistas a terceros. Este sistema es válido siempre que no sea en perjuicio de la sociedad y de los demás socios.

Este derecho de cesión del voto, como ya expresé, tiene un fundamento económico, puesto que son los socios quienes corren el riesgo sobre las decisiones adoptadas en la sociedad. Asimismo, el derecho al voto es considerado como un derecho disponible que forma parte de la esfera patrimonial del socio, por lo que resulta coherente que el socio pueda realizar los actos jurídicos que crea conveniente, aunque este derecho también tiene sus límites.

Exponen Gutiérrez Camacho (1999) y Sánchez Linde (2008)que desde el punto de vista jurídico, el derecho de voto no debe confundirse con el derecho de emisión del voto, porque la emisión del voto es un acto jurídico unilateral, no recepticia, destinada a unirse con el resto de accionistas que votan en un mismo sentido, con el objeto de expresar la voluntad de la sociedad; dicha emisión de voto, debe reunir todos los requisitos legales y no debe estar viciada.

Sobre la legalidad de los sindicatos de acciones como lo expresé en la generalidad de los contratos parasocietarios, soy de la opinión que a pesar de no tener una regulación especial, no es un impedimento para su implementación, siendo su fundamento los principios generales del derecho, la teoría general de los contratos y la licitud de su objeto. Este tipo de pactos extraestatutario, tiene como objetivo convenir una estrategia conjunta de adopción de decisiones sociales, que en algunos casos pueden estipularse un sistema de sanciones para el que se salga del guión acordado.

Es importe identificar en los contratos de sindicación de voto, los pactos de control. Estos acuerdos siguen la regla de reglamentar las actuaciones y pautas de comportamiento de los socios. Desde la óptica privada, estos contratos tienen como fin reducir los conflictos entre los socios en relación al control de la sociedad, siendo generalmente conflictos de minoría o de mayoría (Sáez Lacave, 2009 \& Luceño Olivas, 2010).

Los pactos de control, pueden darse entre socios con poder de control y socios sin poder de control, se trata en este caso de regular las relaciones 
entre unos y otros socios, evitando que el de control de poder se aproveche de su poder de decisión. Cuando se trata de pactos entre todos los socios, se trata de articular las formulas más productivas para ejercitar el control de forma conjunta y superar situaciones de bloqueo.

Concluyo señalando que la sindicación de acciones persiguen un fin, que no es precisamente la de reducir situaciones de conflictividad, sino que la contratación permite consensuar los derechos y deberes de los socios cuando los previstos en el contrato social y en la ley no se consideren apropiados, siendo así, un instrumento de mucha utilidad en las sociedades en donde existe un buen número de accionistas, es decir, en sociedades abiertas.

\subsubsection{Modalidades de Sindicato de voto}

En las Jornadas sobre convenciones de voto y sindicación de acciones en las sociedades anónimas, Bolsa de Comercio de Buenos Aires, 1966, se sostuvo que dentro de los sindicatos de mando o de voto puede hacerse la siguiente clasificación:

a) Por la condición de las acciones sindicadas: Con depósito de títulos o sin depósito de título. En el caso de nuestro sistema, las acciones sindicadas deben ser transferidas en propiedad cuando se hace por vía de fideicomiso y en caso contrario, depende de lo acordado en el contrato privado, en el caso de actuar con poder de representación.

b) Por la clase de acciones: Ordinarias, plurales, nominativas, al portador. En Nicaragua no prima el voto plural, porque en el Art. 254 del Código de Comercio establece que cada acción da derecho a un voto, no siendo aplicable porque altera la proporcionalidad entre el valor nominal de la acción y el derecho al voto.

En el caso de las acciones ordinarias, son aquellas sometidas al régimen normal, es decir, atribuyen a sus titulares el régimen normal de los derechos y obligaciones integrantes de la condición de socio. Asimismo, el sistema nicaragüense reconoce las acciones nominativas y al portador (Art. $224 \mathrm{Cc}$ ).

c) Por la finalidad: De mando, de defensa. El sindicato de mando, persigue como finalidad ejercer influencia sobre el mando de la sociedad, con el propósito de imponer a la sociedad una determinada política de 
dirección. Están dirigidas al gobierno de la sociedad, y defender una mayoría dominante. En el caso de la sindicación de defensa, se refiere a la agrupación de accionistas minoritarios que se encuentran aislados, se unen por medio de este método y se hacen representar por medio de un representante o síndico (Lasowsky \& Pena, 2010).

d) Por el límite de tiempo: Para un solo acuerdo, para un período determinado.

e) Por la forma especial o indirecta: Voting trusts, contrato de report, arriendo de acciones. El sindicato por medio de voting trusts, fue objeto de estudio. En el caso de contrato de reporto, es un contrato de crédito, mediante el cual, el reportado requiere de una suma de dinero, por la cual transfiere al banco, la propiedad de uno o varios títulos valores, que cumplen una función de garantía. El banco a su vez, una cancelado el crédito, devuelve los títulos en especie o su equivalente. En el caso del alquiler de acciones, a través de este servicio, quien posee títulos de empresas cotizadas de la Bolsa pueden cederlos durante un determinado a cambio de un determinado tipo de interés. De esta forma, se puede obtener una rentabilidad extra por aquellas acciones con las que no se tiene previsto operar en un plazo determinado además de ahorrarse la comisión de custodia (Fernández, 2008).

\subsubsection{Sindicato de voto en una sociedad conjunta}

En este tipo de contrato los socios cooperan en la relación de alguna actividad empresarial, tiene por finalidad cooperar en proyectos de forma conjunta para lo cual requieren canalizar esa colaboración en forma de un vehículo o instrumento societario, denominado sociedad conjunta. La decisión estratégica de las empresas, constituye una forma de crecimiento empresarial externo, que tiene como objeto el control interno de una sociedad, existiendo una relación muy estrecha entre el nivel de crecimiento empresarial y la toma de control entre las sociedades (Galeote Muñoz, 2008).

Como primer paso, es necesario que se produzca una decisión de dos o más empresas, que tienen por finalidad crecer, una vez creado ese fin, las partes ponen en marcha un proceso jurídico, sin olvidarse de las consecuencias económicas que este tipo de proceso trae consigo.

Esta forma de cooperación y alianza entre empresas se revela como un procedimiento intermedio entre la forma de crecimiento interno y externo. Son 
sociedades que comienzan a participar conjuntamente en el negocio de otra o una de la otra. Esta forma contractual, no surge simplemente de un solo acto formal, sino que es el resultado del proceso de negociaciones entre los socios que culminan con la adquisición de un determinado nivel de control. Llegado a este punto se consideran la gran cantidad de documentos manejadas como las diferentes denominaciones y eficacia jurídica de las diferentes ordenamientos, siendo dos principales inconvenientes con los que se encuentran los socios en este tipo de proceso, muchos de estos acuerdos no pasarán a los estatutos convirtiéndose en contratos parasociales, por lo que la sociedad conjunta se regula por dos instrumentos: los estatutos y acuerdos extraestatutorios. Estos acuerdos son firmados por todos o algunos socios y no acceden al ámbito público a través de los estatutos, sino que quedan en el ámbito privado de los firmantes, lo cual no implica que no puedan acceder al texto estatutario y Registro Público Mercantil. Por lo tanto, la adquisición de acciones o participaciones, el préstamo de acciones y valores y los pactos parasociales, son entre otros, instrumentos claves para adquirir y mantener determinado nivel de control conjunto en una sociedad, siendo los sindicatos de votos los más adecuados para ejercer la influencia decisiva en la sociedad conjunta cuando existen varios accionistas, permitiendo asimismo, obtener determinado nivel de control en las sociedades (Galeote Muñoz, 2008).

María del Pilar Galeote Muñoz (2008), concluye que los sindicatos de votos es actualmente una de las figuras jurídicas más utilizadas en el derecho de los negocios, puesto que el deseo no es más que entrar en el capital de una compañía y de alcanzar su control, ante la dificultad financiera de llevarlo a cabo por una sola empresa y el deseo de aminorar el riesgo que la operación supone, suelen ser varias las empresas que se deciden a llevar a cabo esta tarea. En este contrato es necesario que se prevea una cláusula en la que se contemple el posible incumplimiento de las obligaciones de los sindicados, es decir, una cláusula que disuada a los sindicados de posibles incumplimientos, en concreto, que obligue a la indemnización de daños y perjuicios, acompañada de una pena sustitutoria de la cuantificación de los daños ocasionados, siendo ideal que se establezcan el procedimiento para calcularlo cuando no se establezcan cifras concretas. Se recomienda una cláusula de resolución de contrato entre las partes y una cláusula de arbitraje.

\subsubsection{Accionistas significativos}

Es una figura reconocida en el derecho español, en espacial en las sociedades cotizadas. Este accionista es aquel socio que por sí solo o por acuerdo entre varios socios, es titular de derechos de adquisición de acciones con derecho al 
voto, siempre que tales derechos superen un límite fijado por el sistema español que es de un 3\% en adelante. Cuando la persona no accionista ha suscrito contrato en virtual del cual tiene derecho a suscribir acciones por el $3 \%$ o más de capital, es considerada como cuasi-accionista. Este personaje adquiere una influencia política dentro de la empresa. Cuando el acuerdo consiste en un pacto parasocial, pueden afectar la transmisión de las acciones o ejercicio de derecho al voto, tienen por objeto ejercer influencia en la sociedad. Este tipo de pacto es reconocido en el Real Decreto 1/2010 Arts. 30 a 535, decreto que derogó el Art. 112 de la Ley de Mercado de Valores de España (Mateo de Ros, 2009 \& Paz-Ares en Uría-Menéndez, 2003).

Nuestro sistema, en la Ley de Mercado de Capital, Ley No. 587, Aprobada el 26 de Octubre del 2006 Publicado en La Gaceta No. 222 del 15 de Noviembre del 2006, se refiere a la participación accionaria significativa (Art. 44 y siguiente), en este caso requiere el $20 \%$ del capital social, siendo una figura análoga a la señalada en el sistema español.

\subsection{Sindicato de bloqueo}

Los sindicatos de bloqueo, son convenios por medio del cual los accionistas se comprometen a no transferir sus acciones o limitar su transferencia durante cierto tiempo, pueden ser con retención de títulos, en la que el accionista retiene su título y con transmisión del título, en este caso el accionista se desprende del título transmitiéndolo al mandatario o representante(Castillo Chaves, 2010).

Javier Corrales (2010), Sáez Lacave (2007),exponen que el caso típico de bloqueo es el que se produce cuando en una sociedad existen dos socios o grupos de socios que ostentan un porcentaje de capital similar, por lo que se necesitan mutuamente para tomar decisiones y en caso de enfrentamiento puede llevar a paralizar el funcionamiento de la sociedad, este conflicto puede producirse tanto en el consejo de administración como en la Junta General. Superar este bloqueo puede ser insuperable a nivel societario y requiere ser conocido por los tribunales, surge así los sindicatos de votos de bloque y muchos de ellos conducen a los socios a forzar la venta de su paquete accionariales. El citado autor señala que los acuerdos pueden recaer en:

- Venta de la compañía:

- Venta únicamente de uno o varios socios a un tercero.

- Otorgamiento de opción de compra o de venta a favor de uno o varios socios.

- Liquidaciónpactada. 
Coincidente con María del Pilar Galeote Muñoz (2008), los más eficaces sindicatos de bloqueo, son los de sometimiento a autorización, así como los que otorgan derechos de adquisición preferente a favor del resto de sindicados. En el de sometimiento de la transmisión a autorización, se puede ejercer y limitar la entrada de nuevos accionistas y por lo tanto, mantener un determinado nivel de control, evitando además, una posible dilución en el capital de los sindicados. Respecto a los límites de esta cláusula, resulta conveniente que se incluyan las causas de denegación de la referida autorización en el contrato de sindicación. Asimismo, se consideran válidos los sindicatos de bloqueo en los que se otorga un derecho de adquisición preferente ya sea a favor del resto de accionistas, de un tercero o de la sociedad.

Igualmente coincidente con Gutiérrez Camacho (1999), el sindicato de bloqueo, constituye un completo sindicato de voto, sobre todo en los países en donde el sindicato de acciones, no está legalizado expresamente. Generalmente el sindicato de bloqueo, persigue los siguientes fines:

a) Mantener cohesión y estabilidad de la plana gerencial con el propósito de mantener por un tiempo determinadas políticas sociales.

b) Cuando se celebran contratos de colaboración empresarial y la otra parte necesita que se garantice continuidad con las políticas sociales.

c) Para mantener los mismos socios que actualmente integran a la sociedad, sea por los requisitos de los socios o porque les interesa que ingresen a la sociedad determinadas personas - puede ser la competencia-

Nuestro Código de Comercio no prohíbe los sindicatos de bloqueo, pero reconoce en numerosos artículos la transmisibilidad de las acciones (37.4225-226-229-230-231-232-233-234 CC). También, reconoce que es válido pactar limitaciones referidas a la forma de transmitirla, dejando siempre una puerta abierta que permita su transmisión. Ciertamente existe la posibilidad de establecer limitaciones, pero sin que ellos signifiquen una prohibición absoluta. En este sentido, los pactos parasocitearios entran a jugar un papel muy importante en relación al ejercicio del derecho del accionista de separarse o transmitir sus acciones a otros socios o a terceros.

En mi opinión, la licitud de los sindicatos de bloqueo se fundamenta en la libertad de contratación con sujeción a las leyes, la moral y el orden público (Art. 2437 Código Civil. En relación a los límites para su validez los sindicatos de bloqueo para que sean lícitos deberán cumplir con las siguientes condiciones: 
a) No deben ser acuerdos en los que se imponga una limitación absoluta a la libre transmisión de acciones.

b) Que no contravengan la ley y los estatutos de la sociedad.

c) En algunas legislaciones establecen un plazo no mayor de 10 años, en nuestro sistema no establece plazo. Excepto cuando se haga tipo contrato fiduciario.

d) Validez de consentimiento, objeto y causa como elementos esenciales de los contratos.

\subsection{Sindicato financiero}

Según Walter Gutiérrez Camacho (1998) y Daniel Echaiz Moreno (2005), el sindicato financiero se centra en los títulos (acciones, participaciones, bonos, etc) emitidos por la sociedad y por su valor de mercado, sean cotizados en bolsa o no. Este tipo de sindicato, no manifiesta interés en el control de la sociedad, se trata de actos especulativos destinados a no invertir, sino a especular. En este caso los sindicados mantendrán los títulos de la sociedad por el tiempo que sean necesarios (corto plazo), hasta alcanzar la renta esperada por su transferencia.

La resolución No. 055-2002-SUNARP-TR-L del 23 de julio del 2002 del Tribunal Registral de Perú, define los sindicatos financieros como aquellos que tienen por finalidad obtener máximas ganancias en la inversión de acciones mediante un juego especulativo. Este grupo puede ocasionar cambios en el valor de las acciones que se cotizan en bolsa, participar en la suscripción, beneficiándose de esta manera con la diferencia entre el valor de los aportes y el resultado de la venta de acciones.

\section{Los sindicatos financieros se clasifican en:}

Sindicato de emisión o colocación: Significan la suscripción de valores mobiliarios para lanzarlos al mercado. Se emiten acciones para distribuirlos al público, obteniendo un beneficio. Tiene como objetivo una inversión importante de capital (Echaiz Moreno, 2005 \& Gutiérrez Camacho, 1999).

Sindicato de garantía: Procura la colocación de valores mobiliarios a cambio de una comisión (Echaiz Moreno, 2005 \& Gutiérrez Camacho, 1999).

Sindicato de especulación: Procuran alzas o bajas de determinados valores en la bolsa con finalidad y objetivos especulativos (Echaiz Moreno, 2005; Gutiérrez Camacho, 1999). 
Sindicatos de resistencia: Tienen por finalidad agrupamiento o bloqueo de títulos de un grupo de accionistas con el fin de defender la cotización bursátil, limitándose la transferencia de acciones a terceros (Echaiz Moreno, 2005 \& Gutiérrez Camacho, 1999).

\subsection{Sindicato de la administración}

Este tipo de sindicato es uno de los más controversiales. Puede suceder que las normas societarias sobre la administración sean insatisfactorias desde el punto de vista de los intereses de los socios, se hace necesario contar con un instrumento legal que prevea seguridad para los socios, uno de esos instrumentos pueden ser los contratos de administración. Estos contratos vinculan a los socios con los directores o a los directores con terceros. Por lo que estamos ante un sindicato de administración cuando los directores comprometen su actuación en la sociedad (Echaiz Moreno, 2005 \&. Gutiérrez Camacho, 1999).

Por la condición del director y la función que ejerce estos contratos han sido objeto de debate en relación a su legalidad, son visto muy a menudo por su desconfianza, porque limitan la libertad de los directores en relación al ejercicio de sus funciones. En los sindicatos de administración quienes se obligan son los directores a diferencia de los sindicatos de acciones, que son los socios comprometiendo su voto. En los sindicatos de administración los directores deben actuar en beneficio de la sociedad y en favor de un grupo de socios, sin embargo, no olvidemos que los administradores pueden ser socios de la empresa, como es el caso de nuestro Código de Comercio.

El problema que se plantea en este caso, es hasta qué punto de vista los administradores pueden convenir en contraposición de los estatutos societarios y alterando normas imperativas que en materia de organización social ha sido establecida por las leyes especiales. Si un contrato de este tipo, aún con la firma de los socios, podría implicar una modificación al pacto social que colisionaría con el acta constitutiva y estatutos. En conclusión, puede ser contratos que no lesionen derechos de los establecidos en el contrato social y leyes respectivas. En la práctica y la doctrina se han considerado válidos: la elección del presidente del directorio; nombramiento de funcionarios de la sociedad; aprobación de transferencia de acciones u otras participaciones(Gutiérrez Camacho, 1999).

Analizando las funciones de los administradores, nuestro Código de Comercio limita su actuación en la esfera del objeto social, en la forma que determinen los estatutos (Arts. 124.4, 203, 205.5, 243, 245 Cc). Cualquier extralimitación de sus funciones éste se obliga frente a terceros, sea que haya actuado de buena o de 
mala fe y responde civil y penalmente según sea el hecho indebido cometido. Se observa que la actuación del administrador es bien restringida al pacto social, de manera que un sindicato de votos, no debe recaer en situaciones ajenas al pacto social, al igual que en los estatutos, este órgano se debe a la Junta General de Accionista.

\section{Conclusiones}

Validez de los contratos parasocietarios y en particular los sindicatos de acciones. Los contratos parasocietarios son una realidad en la práctica empresarial, la doctrina y la jurisprudencia de los países del continente americano y europeo. Es evidente el reconocimiento y validez de estos contratos en los sistemas jurídicos estudiados, independientemente de la existencia o no de una regulación especial. En nuestro país, el Código de Comercio de que data de 1917 no los regula expresamente, ni tampoco existe referencia jurisprudencial en la Corte Suprema de Justicia; pero, de acuerdo a este estudio y en concordancia con la legislación comparada, los sindicatos de acciones son válidos y eficaces en Nicaragua, por las siguientes razones:

En primer lugar, tiene como fundamentación el principio de autonomía de la voluntad y libertad de contratación regulado en los Art. 32 Cn, Arts. 1831, 1836, 2435, 2437. Del Código Civil.

En segundo lugar, son contratos oponibles frente a terceros, siendo aplicable el principio de relatividad de los contratos regulado en el Art. 2439, en la que se pone de manifiesto que los contratos tienen efectos solamente entre las partes y sus herederos, aunque se reconocen excepciones a la regla de la inoponibilidad, como es el caso contemplado en el Art. 2439 párrafo segundo del Código Civil que se refiere a los contratos con estipulación a favor de terceros; los casos de sindicatos totalitarios, en donde los socios que pactan el acuerdo corresponden a la misma cantidad de acciones o de capital social de la Junta General, equiparándose como Juntas Universales; en aquellos casos en donde se aplica la regla de los contratos civiles cuando los socios ceden derechos de créditos a terceros.

En este último caso, no debe confundirse con lo regulado en el Art. 131 del Código de Comercio, en relación a los convenios entre socios y terceros que se pactan en los estatutos, este convenio no es válido, cuando el prestamista de dinero participa en las ganancias, declarando la ley como un acuerdo nulo e ilegal; en este supuesto, cuando se trata de convenios parasocietarios de este tipo, debe tomarse en cuenta lo anterior, pudiendo las partes hacerlo como una 
cesión de crédito, situación nos lleva a considerar la simulación de contratos que se pueda presentar en los contratos parasocietarios cuando se encubre el carácter jurídico del contrato bajo la apariencia de otro (Art.2220 C), pero, establece que para su validez no deben perjudicar a otro y tener un fin licito.

En tercer lugar, el contrato de sindicación de acciones debe cumplir con un interés particular que tendrá su efecto a lo interno de la sociedad, es decir, el acuerdo o convenio no debe ser contrario a la ley, moral y orden público (Art. 2437 C), fundado en una actuación de buena fe objetiva y subjetiva, es decir, una actuación conforme a derecho y a la confianza que se delega en un tercero accionista o no síndico.

Aportes del derecho comparado a nuestro sistema jurídico. En particular, la legislación de Perú, Brasil, Uruguay, España, aportan a nuestro sistema dos elementos significativos para la validez y eficacia de los contratos de sindicación de acciones; siendo la comunicación y la jerarquía de estos pactos en relación al contrato social y estatutos.

En primer lugar, la comunicación o notificación del acuerdo parasocietario a la sociedad constituye un valor agregado para que el sindicato de acciones surta efectos y sea reconocido por la sociedad mercantil. Si bien, en nuestro sistema los artículos 36, 37 del Código de Comercio de Nicaragua, no establecen la inscripción de dichos acuerdos, en este caso, los socios al constituir la sociedad pueden llenar este vacío estableciendo una cláusula en la que se permita la inscripción de los contratos parasocietrios, basándose en el principio en el principio de autonomía de la voluntad y libertad de contratación (Arts. 1836, 2439,2479 C). Sin embargo, en el caso de no existir pacto expreso en los estatutos, los socios podrán acordar en Junta General de accionista crear este derecho como requisito de validez, tanto si se lleva a cabo por accionistas minoritarios o mayoritarios.

La ventaja de crear este mecanismo de comunicación, es para lograr el reconocimiento que la sociedad mercantil le otorgue a los convenios de este tipo. Asimismo, les otorga seguridad jurídica a los socios que pretenden ejercer cierta influencia en las decisiones de Junta General y Junta Directiva; así como también para mantener el equilibrio de poder interno en la sociedad. La comunicación puede obtenerse por otra vía, es decir, por la inscripción del contrato parasocietario en el Registro Mercantil. Parto de este criterio, porque considero que la Ley General de Registro Público No. 698, es bastante amplia al admitir en los considerandos la posibilidad de inscribir y darle publicidad a los actos y contratos mercantiles (Arts. 4,153, 156 numeral 8). 
El segundo lugar, los pactos parasocietarios son acuerdos que están ligados al contrato social (Art. 1877 Cc), es decir, que su existencia depende de la validez y eficacia del contrato social, de manera que no pueden ser contrarios a éstos. Asimismo, no debe entenderse como una sociedad paralela a la sociedad mercantil de la que son socios las partes del contrato parasocietario, simplemente se considera como un acuerdo de organización en la que se establecen intereses que no afectan a la sociedad, pero vinculada a ella (Arts. 330, 331, $333 \mathrm{Cc}$ ). En este caso, la doctrina establece que los pactos de organización son los más conflictivos, siendo así el contrato de sindicación de acciones, por cuanto tienen como finalidad reglamentar el funcionamiento de la sociedad, así como tomar decisiones de control societario. En este caso, los accionistas deben tener el cuidado de no establecer cláusulas que contradigan lo establecido en los estatutos. Por ejemplo: Un sindicato de accionistas puede reglamentar el ejercicio del derecho a la información, sin violentar lo pactado en el contrato social y la ley, al ser éste considerado como un derecho irrenunciable (203 Cc).

\section{En tercer lugar, el Tribunal Registral del Perú en Resolución No.} 055-2002-SUNARP-TR-L, deja suficientemente claro que los acuerdos entre socios "Contratos parasocietarios" no constituyen una nueva sociedad comercial, con derecho a inscripción para obtener personalidad jurídica, sino que los convenios de sindicación de acciones, no es otra cosa que el contrato celebrado entre la pluralidad de sujetos, accionistas de una sociedad, con el fin de defender sus intereses frente a los otros accionistas o grupos de accionistas. La suma de acciones convierte así este grupo con capacidad de decisión o de defensa, que no existiría en la sindicación sino se hubiese logrado. En base a los criterios anteriores la resolución señala que los convenios de accionistas no constituyen otra persona jurídica independiente de la sociedad de la cual son accionistas los sindicatos, pero son estipulaciones que forman parte de los estatutos de la sociedad que la integran, las cuales pueden ser objeto de inscripción. Esta resolución es un aporte para conocer los efectos de los contratos parasocietarios, inclusive en nuestro sistema legal. En este sentido, el Código de Comercio de Nicaragua reconoce expresamente que toda sociedad comercial constituye una persona distinta a los socios y en consecuencia, todo acuerdo de socios no constituye una sociedad distinta a los socios (Arts. 119, 330, $331 \mathrm{de} \mathrm{Cc).}$

La naturaleza jurídica de los sindicatos de acciones. Me permito adoptar como fundamento lo señalado en la mayoría de la doctrina consultada en este papers, es decir, los contratos parasocietarios "Sindicatos de acciones", son contratos plurilaterales, extraestatutario, lícito, informar, consensual, accesorio, mercantil, temporal, de interés común: 
- Es un contrato plurilateral autónomo. En este caso, el contrato de sindicación de acciones es colectivo, todos los socios tienen un mismo fin (Art. 3175 C).

- Es un contrato asociativo, tiene como objeto influir en la sociedad desde afuera. Es aplicable de manera analógica los artículos de las asociación en participación y asociación momentánea (Arts. 330, 331, 333 Cc).

- Es accesorio, como ya quedó expuesto en las conclusiones, este contrato depende del contrato societario. La nulidad del contrato societario provoca la nulidad del contrato de sindicación (Art. 1877 Cc).

- Es un contrato empresarial. Se trata de la agrupación de acciones más que de las personas, debe existir de previo una persona jurídica, por lo que son aplicables las disposiciones del Código de Comercio y de manera supletoria el Código Civil (Arts. 1,2,118, 202 Cc).

- Nuestro sistema no requiere ninguna formalidad, pero las partes pueden establecer condiciones de formalidad para su inscripción en el registro de la sociedad y en el caso de que las partes requieran inscribirlo en el Registro Mercantil, debe elevarse a instrumento público a través de Notario (Arts. $111 \mathrm{Cc}$ ).

- Los contratos de sindicación de acciones, no requieren plazo de vigencia, pero en la doctrina y derecho comparado se ha comprobado que son temporales, siendo necesario en este caso pactar un tiempo determinado de vigencia.

- Basta que las partes manifiesten su consentimiento de manera verbal o escrita para que el contrato tenga plena eficacia (Art. 2449 y siguiente del Código Civil).

Aplicación analógica de otras disposiciones del Código de Comercio vigente a los acuerdos entre socios en relación a los sindicatos de acciones. En mi opinión, existen otras disposiciones del actual Código de Comercio que deben ser consideradas por los accionistas a la hora de pactar contratos parasocietarios, en especial los sindicatos de acciones:

- El Art.251 Cc que se refiere al derecho de los socios de agruparse en acciones que representen la vigésima parte del capital. El contrato social y los estatutos no pueden prohibir este derecho, pudiendo los socios si lo creen conveniente reducir el porcentaje señalado. 
Este artículo de una manera general reconoce diferentes formas de agrupaciones accionarias, independientemente que no se haya pactado en los estatutos. Asimismo, los Arts. Art. 251, y 252 Cc reconoce el derecho de los accionistas de solicitar a la Junta Directiva que se convoque a una Junta Extraordinaria, garantizándole este derecho a través de la vía judicial en el caso de negarse la solicitud.

- La impugnación de los acuerdos societarios. En este punto el Art. 261, reserva el derecho de impugnación a los socios, no puede un acuerdo societario de sindicación, derogar este derecho, puesto que cualquier accionista independiente del número de acciones podrá ejercer este derecho.

- Las acciones emitidas por debajo de la par. Constituye un medio de defensa del capital social. En este caso los Arts. 124.8, 224, 249, 259 $\mathrm{Cc}$, establecen prohibiciones que se les impone a los socios y de los cuales no puede ser objeto de contrato parasacietarios. Es decir, no podrán los sindicatos de accionistas emitir acciones por debajo de la par, ni tampoco distribuir dividendos tomándolos del capital social, así como tampoco, no podrá disponer del fondo de reserva legal.

Figuras afines a los sindicatos de acciones. El voting trusts es una figura idéntica a los contratos de fideicomiso de acciones, siendo aplicable en este caso las disposiciones de la Ley sobre Contrato de Fideicomiso No. 741. La condición para su validez es que sean lícitos de acuerdo a la Constitución Política y las leyes ordinarias. Puede crearse sindicatos de mando, sindicatos de defensa a través de los contratos de fideicomiso y en este caso se requiere la inscripción en el libro de acciones de la sociedad y el cumplimiento de los criterios señalados en la ley especial (Arts. 2,3,5,14,9, 30,48 Ley No. 741). Uno de los problemas que se presentan en la práctica sobre relación entre el fiduciario y fiduciante en el ejercicio de los derechos económicos y políticos, en estos casos el contrato debe delimitar la frontera de ambas partes para evitar confusión, así el fiduciario que es quien ostenta la titularidad de las acciones tiene derecho de ejercer los derechos políticos y económicos de los accionistas en cada Junta, mientras esté vigente el contrato.

Otro contrato similar, lo constituye el voting agreement, simplemente es la puesta en común de los socios, puede requerir de poder de representación o no. en nuestro sistema podemos hacerlo a través de la figura del mandato regulada en los artículos 3293, 3310, 3311 del Código Civil). 
Otras figuras relevantes en nuestro derecho, son las sociedades conjuntas y los socios significativos. La primera, la tenemos como acuerdo entre socios de diversas sociedades, aplicamos nuevamente en este caso, lo que hemos venido reafirmando en todo momento, es decir, que es un contrato asociativo, siendo aplicable las disposiciones del Código Comercio (Art. 330, 331, 333 Cc). La segunda figura, lo tenemos bastante claro en el sistema comercial a través de la Ley de Mercado de Capital No. 587 que se refiere a la participación accionaria significativa, señalando a diferencia de la Ley Española, que en este caso se requiere el 20\% del capital social.

El sindicato de bloqueo y de administración. Ambas son modalidades de los sindicatos de voto, los acuerdos recaen en los derechos políticos de los socios, es decir, en el derecho al voto, los socios planifican estrategias conjuntas de adopción de acuerdos sociales, lo que permite consensuar los derechos y deberes de los socios cuando los previstos en el contrato social y en la ley no se consideren apropiados. En el sindicato de voto, nos encontramos con la cesión del voto a un tercero, lo que no significa violación a la ley y estatutos. Nuestro código no establece limitante en el ejercicio de este derecho, por lo que nuevamente es una facultad de los socios según la autonomía privada. En este caso, los socios ceden sus derechos a terceras personas para ejercer el derecho de voto en los órganos de la sociedad.

El sindicato de bloqueo, tiene como objetivo limitar ciertos derechos de los accionistas. Ambas formas de sindicación, son legales, en caso de diferencias le son aplicables los principios generales del derecho, la teoría de las obligaciones y contratos. En la práctica societaria se discute sobre la legalidad de los sindicatos de bloqueo, pero en mi opinión, son válidos, siempre que cumplan los siguientes requisitos: que no impongan limitaciones absolutas sobre la transmisibilidad de acciones y que no contravengan la ley y los estatutos; que se pacte por un tiempo determinado y que el contrato cumpla con los elementos esenciales para su validez.

El sindicato de administración, puede funcionar siempre que el órgano colegiado, actúe dentro de la esfera de su competencia delimitada en el objeto social de la sociedad, toda actuación contraria, puede significar una violación a los estatutos (Arts. 124.4, 203, 205.5, 243, 245 Cc). 


\section{Lista de Referencias}

Araya, T.M (2011). Reflexiones sobre los Acuerdos de Accionistas. Revista Argentina de Derecho Empresario del 2011. Recuperado el día 5 de noviembre de 2011. En http://www.ijeditores.com.ar/articulos.php?idarticulo=42155\&print=2

Álvarez López, J. C (2009). Pactos societarios en las sociedades de responsabilidad limitada. Consultado Recuperado el 2 de noviembre de 2011. En Internet (http://www.legaltoday.com/practica-juridica/sociallaboral/societario/pactossocietarios-en-las-sociedades-de-responsabilidad-limitada).

Alterini, A. A (1999). Contratos Civiles, Comerciales y de Consumo. Buenos Aires. Albeledo Perrot.

Berges Angós, I (2009). Pactos parasociales. Recuperado el 28 de agosto de 2011 en www.diariolaley.es. 28 de mayo de 2009.

Broseta Pont, M (1990). Manual de Derecho Mercantil. 8va ed. Madrid, Tecnos

Castillo Chaves, A.E (1998). Los pactos parasociales. Recuperado el 7 de noviembre de 2011. En http://www.poderJudicial.go.cr/escuelajudicial/archivos \%20 actuales/documents/revs_juds/rev_jud_98/artículos/09_par.html

Caamaño, C. R (S.F). Sindicato de acciones. Recuperado el 28 de agosto de 2011 en www.derecho-comercial.com

Corrales, J (2010). Situaciones de Bloqueo Societario. Newsletter - Julio 2010BarcelonaRecuperado el 7 de noviembre de 2011. En www.marcolegal.com,

Escobar Fornos, I (2000). Derecho de Obligaciones. 2da edición, Managua, Hispamer.

Echaiz Moreno, D (2006). La Juntas de Socios Contemporánea, Revista del Foro, Lima --Perú.

Echaiz Moreno, D (2005). Estudio de Derecho Societario. Lo errado, lo inconcluso y lo imprevisto en la Ley General de Sociedades. Lima, Perú

Echaiz Moreno, D (2005). Propuestas para una Reforma de la Legislación Societaria En el Perú. Vniversitas. Bogotá (Colombia) N 110: 191-224, julio-diciembre de 2005. Sánchez González, J (1991). Los convenios y sindicato de votos, Madrid, Civitas. Fares, F. S (1963). La sindicación de acciones. . Ed. Abeledo Perrot

Fernández, D (2008). El País.com. Vivir del alquiler de las acciones. Disponible el 23 de octubre de 2011 Disponible en http://www.elpais.com/articulo/dinero/ inversiones/Vivir/alquiler/acciones/elpepueconeg/20081116elpnegdin_2/Tes.

Gutiérrez Camacho, W (1999), “Contratos parasocietarios”, en: Diario Gestión, Lima, 9 de Septiembre. Recuperado el 28 de agosto de 2011. En http://www.teleley. com/1gutierrez-52.pdf

García Rendón, M (1993). Sociedades Mercantiles. Harla. México. D.F

Guzmán García, J. J \& Herrera Espinoza, J.J (2006). Contratos civiles y mercantiles.--------- (1era ed). Managua. Colección de la Textos de la Facultad de Ciencias Jurídicas-UCA

Galeote Muñoz, M del P (2008). Sindicato de votos en una sociedad conjunta. La ley 38667/2008--. Tribuna Halperin Sociedades Anónimas. Argentina. Depalma 
Luceño Oliva, J. L (2010). Los pactos parasociales como instrumento de protección del socio minoritario. Una propuesta de contenido mínimo. Noticias jurídicas. Recuperado el 23 de octubre 2011 en Disponible http://noticias.juridicas.com/ articulos/50-Derecho\%20Mercantil/201004-54987321456.html,

Lasowsky, D \& Pena, V (2010). Convenios de sindicación. Recuperado el 23 de octubre de 2011en http://www.derechocomercial.edu.uy/ReSociSA. htm.

Luceño Olivas, J. L (2010). Los pactos parasociales: instrumento de protección del socio minoritario. Recuperado el 2 de noviembre de 2011 en http://www. legaltoday.com/practica-juridica/mercantil/societario/los-pactos parasocialesinstrumento-de-proteccion-del-socio-minoritario.

Mosquera Alcocer, S.J (2009). Tesina: La Sindicación de Acciones en 11 DerechoComparado. Quito, Universidad Andina Simón Bolívar Sede Ecuador

Molina Sandoval, C. A (2005). Fideicomiso Societario. Bases para una mejor Utilización de la figura fiduciaria. El Derecho. Recuperado el 1 de octubre de 2011 en http://works.bepress.com/carlos_molina_sandoval/10.

Matta y Trejo, G. E (1980), Otra vez en torno a los pactos de sindicación entre accionistas.

LA LEY1980-C, 1001

Moglia Claps, G. A (2011). Contrato Plurilateral y Contrato Bilateral. La Sociedad como Contrato Plurilateral en la Regulación de La Ley de Sociedad Comerciales. Efectos.Recuperado el 11 de septiembre de 2011 en http://www. salvador.edu.ar/juri/aequitasNE/nrotrece/DERECHO\%20COMERCIAL. pdf,. Universidad del Salvador, República de Argentina

Mateo de Ros, R (2009), Los accionistas siginificativos de la sociedad anónima cotizada Pactos parasociales, derechos políticos y principios de igualdad de trato. Recuperado el 8 de octubre de 2011 enhttp://centrogobiernocorporativo. ie.edu/files/Accionistas\%20significativos.pdf

Model bussiness Corporation. Act (2005). Tercera edición. Recuperado el 2 de noviembrede 2011. Disponible en internet: http://greatlakesval.com/wpcontent/uploads/2011/08/Model-Business-Corporation-Act.pdf

Palmiter, A (2009). Corporations: Examples \& Explanations. United State. P. 529. Recuperado el 2 de noviembre de 2011. Disponible en internet: http:// books.google.com.ni/books?id=VC8E5JOGC3QC\&pg=PA529\&lpg=P A529\&dq=Manson+v.+Curtis, + Court + of + Appeals + of $+\mathrm{New}+$ York, $+119+$ N.E.+559+\%281918\%29\&source=bl\&ots=KvpQ2LSDhr\&sig=yQQFGy0Je08XSSy108NEVjLpnE\&hl=es-419\&sa $=X \&$ ei $=$ j62iUO26E4268wSP3I

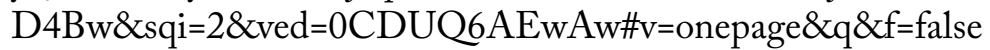

Paz-Ares C (2003). El Enforcement de los Pactos Parasociales. Actualidad Jurídica Uría\& Menéndez. Universidad Autónoma de Madrid. No. 5

Quesnay Casusol, J. M (2009). Los Convenios Parasocietarios. Disponible en internetRecuperado el 23 de octubre de 2011 en http://jquesnay.wordpress. com/los-contratos-parasocietarios/

QuesadaSánchez,A.J(2002).Aproximaciónalafiguradelcontratoendañodeterceronotas introductorias. Recuperado el 2 de noviembre de 2011 en http://noticias. 
juridicas.com/articulos/45-Derecho\%20Civil/200202-65515611023360.html. Sáez Lacave, M. I (2009). Los socios en Derecho Español. Una materia en manos de los jueces. Facultad de Derecho. Universidad Autónoma de Madrid

Sáez Lacave, M I \& Bermejo Gutiérrez, N (2007). Inversiones específicas,oportunismo y contrato de sociedad. A vueltas con los pactos de tag y de drag-along. Facultad de Ciencias Jurídicas, Universidad Autónoma de Madrid.

Sánchez Linde, M (2008). De nuevo, en torno a la emisión del voto del socio, como posible declaración de ciencia o declaración de voluntad en la junta de accionistas. Sentencias de TSJ y AP y otros Tribunales num. 16/2008 (Artículo)., Pamplona SA. Editorial Aranzadi.

Simois Lapeyre, D (2001). Convenios de Sindicación de Acciones. KPMG, Uruguay, disponible en www.kpgm.com.uy

Vicent Chuliá, F (2004). Introducción al Derecho Mercantil. Valencia 17a edición. Tirant Lo Blanch

\section{Leyes nacionales}

Constitución Política de Nicaragua, Publicada en el 9 de enero de 1987, Gaceta Número 94 del 30 de abril de 1987; Reformada: 1) El 30 de enero de 1990, Publicada en Gaceta Diario Oficial No. 46 del 6 de marzo de 1990;2) El 1 de febrero de 1995, Ley No. 192, Publicada en Gaceta Diario Oficial No. 124 del 4 de julio de 1995; 3) El 18 de enero de 2000 Ley No. 330 Publicada en Gaceta Diario Oficial No. 13 del 19 de enero de 2000; 4) El 15 de junio de 2004 Ley No. 490 Publicada en la Gaceta Diario Oficial No. 132 de 7 de julio de 2004; 5) El 13 de enero de 2005 en Ley No. 520 Publicada en Gaceta No. 35 del 18 de febrero de 2005 (En sentencia No. 52 de las 8:30 de la mañana del 30 de agosto de 2005 en la que la Corte Suprema de Justicia declara la inconstitucionalidad parcial de la Ley No. 520); 6) El 15 de marzo de 2005 en Ley No. 527 Publicada en la Gaceta Diario Oficial No. 68 de 8 de abril de 2005

Código Civil de la República de Nicaragua Publicado en la Gaceta Diario Oficial 2148 de 5 de febrero de 1904

Código de Comercio Publicado en la Gaceta Diario Oficial No. 248 del 30 de octubre de 1916

Ley No. 698, Ley General de los Registros Públicos. Aprobada el 27 de Agosto del 2009. Publicada en La Gaceta Diario Oficial No. 239 del 17 de Diciembre del 2009 Ley No.741, Ley sobre el Contrato de Fideicomiso publicada en el Diario Oficial No. 11 del 19 enero de 2011

Ley de Mercado de Capital, Ley No. 587, Aprobada el 26 de Octubre del 2006 Publicado en La Gaceta Diario Oficial No. 222 del 15 de Noviembre del 2006

\section{Leyes, reglamentos internacionales}

Ley No. No. 266787, Ley General de Sociedades 19 de noviembre de 1997 del Perú, Publicada el Lima el 5 de diciembre de 1997

Decreto 841/84 B.O. 30/03/1984. Ley No. 19.550 Ley de Sociedades Comerciales, 


\section{Argentina}

Ley No. 2637 Código de Comercio de la República Argentina. 05 de Octubre de 1889 Resolución No. 055-2002-SUNARP-TR-L. Tribunal Registral del Perú. 00036008 del 02 de Setiembre de 2002, http://www.sunarp.gob.pe/precedentes.asp?ID=62

Ley No. 6404 que es de fecha 15 de diciembre de 1976. Brasil

Ley No. 18.046, Sobre Sociedades Anónimas. Publicada en el Diario Oficial de 22 de Octubre de 1981, y actualizada al 14 de Diciembre de 1999.

La Ley No 18.045 de Mercado de Valores, de chile en adelante LMV, se publicó en el Diario Oficial de 22 de octubre de 1981 y ha sido modificada por las leyes: a) No 18.350 , publicada en el Diario Oficial de 19 de octubre de 1984; b) No 18.489, publicada en el Diario Oficial de 28 de diciembre de 1985; c) No 18.660, publicada en el Diario Oficial de20 de octubre de 1987; d) No 18.815, publicada en el Diario Oficial de 29 de julio de 1989; e) No 18.876, publicada en el Diario Oficial de 21 de diciembre de 1989; f) No 18.899, publicada en el Diario Oficial de 30 de diciembre de 1989; g) No 18.919, publicada en el Diario Oficial de 1 de febrero de 1990; h) No 19.221, publicada en el Diario Oficial de 15 de junio de 1993; i) No 19.301, publicada en el Diario Oficial de 19 de marzo de 1994; j) No 19.389, publicada en el Diario Oficial de 18 de mayo de $1995 ;$ k) No 19.506 de 30 de julio de 1997; 1) No 19.601, publicada en el Diario Oficial de 18 de enero de 1999; m) Ley No 19.623, publicada en el Diario Oficial de 26 de agosto de 1999; n) por el Artículo $1^{\circ}$ de la Ley No 19.705, publicada en el Diario Oficial de 20 de diciembre de 2.000; ñ) por el artículo $4^{\circ}$ de la Ley No 19.768, publicada en el Diario Oficial de 7 de noviembre de 2001; o) por el artículo $3^{\circ}$ de la Ley № 19.769, publicada en el Diario Oficial de 7 de noviembre de 2001; p) por el artículo 54 de la Ley No 19.806, publicada en el Diario Oficial de 31 de mayo de 2002, q) por el Artículo $6^{\circ}$ de la Ley No 20.190, publicada en el Diario Oficial de 5 de junio de 2007, y r) por el Artículo $1^{\circ}$ de la Ley $\mathrm{N}^{\circ} 20.343$, publicada en el Diario Oficial de 28 de abril de 2009 Ley SOCIEDADES COMERCIALES No 16.060 Publicación: Diario Oficial. $1^{\circ}$ nov/989 - No 22977. Uruguay

Real Decreto Legislativo 1/2010, de 2 de julio, por el que se aprueba el texto refundido de la Ley de Sociedades de Capital. España

Reglamento del Consejo (CE) no 2157/2001, de 8 de octubre de 2001, por el que se aprueba el estatuto de la Sociedad Anónima Europea.

\section{Jurisprudencia y resoluciones extranjeras}

Sentencia del TS del 26 de febrero de 1991 y del 10 de febrero de 1992. España Sentencia del TS del 24 de septiembre de 1987. España

RDGRN 26 de octubre de 1989. España

Manson v Curtis, Corte de Apelaciones de Nueva York, 119 NE 559 (1918)

Resolución No. 055-2002-SUNARP-TR-L. Tribunal Registral del Perú. 00036008 del 02 de Setiembre de 2002, http://www.sunarp.gob.pe/precedentes.asp?ID=62 